\title{
EFEITO DA ADIÇÃO DO ANTIOXIDANTE BHT E DO ARMAZENAMENTO SOBRE A QUALIDADE DA FARINHA DE CARNE E OSSOS PARA FRANGOS DE CORTE
}

\author{
ALINE MONDINI CALIL RACANICCI \\ Engenheira Agrônoma
}

Orientador: Prof. Dr. José Fernando Machado Menten

Dissertação apresentada à Escola Superior de Agricultura "Luiz de Queiroz", Universidade de São Paulo, para obtenção do título de Mestre em Agronomia, Área de Concentração:

Ciência Animal e Pastagens

\author{
PIRACICABA \\ Estado de São Paulo - Brasil \\ Maio - 2000
}


Dados Internacionais de Catalogaçāo na Publicaçāo (CIP) DIVISÃO DE BIBLIOTECA E DOCUMENTAÇÃO - Campus "Luiz de Oueiroz"/USP

\section{Racanicci, Aline Mondini Calil}

Efeito da adição do antioxidante BHT e do armazenamento sobre a qualidade da farinha de came e ossos para frangos de corte / Aline Mondini Calil Racanicci. . Piracicaba, 2000.

$69 \mathrm{p}$.

Dissertação (mestrado) - Escola Superior de Agricultura Luiz de Queiroz, 2000. Bibliografia.

1. Alimentação animal 2. Antioxidante 3. Desempenho animal 4. Farinha de cameosso 5. Frango de Corte 6. Oxidação 7. Ração 8. Valor nutritivo I. Titulo

$$
\text { CDD } 636.513
$$


Dedico

Aos meus amados pais, Antônio Sérgio e Roseli,

exemplos de amor e dedicação tão importantes na minha vida

Ao meu marido, Osvaldo,

pelo amor e pelo apoio em todos os momento, especialmente os mais dificeis

À minha irmã, Éveri,

pela amizade e companheirismo

Ofereço

À minha amada filha, Jamile, por ser a minha luz e a minha inspiração, todos os dias 


\section{AGRADECIMENTOS}

\section{À DEUS.}

Ao Prof. Dr. José Fernando Machado Menten, pela confiança e pela orientação sempre paciente e serena em todos os momentos.

Ao Prof. Dr. Roberto Dias de Moraes e Silva, pelos ensinamentos, pela palavra amiga e pelo apoio sempre presentes, desde o curso de graduação.

À Multimix - Produtos e Serviços Agropecuários e a todos os seus funcionários e amigos, na pessoa do Dr. João Batista Luchesi, Diretor Técnico, e do Dr. Humberto Del Nery, Gerente Industrial; pelas análises bromatológicas e suporte ao projeto, e pelo aprendizado nos anos que trabalhei na empresa.

À Fundação de Amparo à Pesquisa do Estado de São Paulo (FAPESP) pelo financiamento do projeto e pela bolsa concedida.

À Profa Ivanete Susin e ao Prof. Alexandre Vaz Pires, pela amizade sincera e pelo incentivo em todos os momentos.

À todos os professores do Departamento de Produção Animal pelos valiosos ensinamentos durante o curso de mestrado.

À amiga Oneida Vasconcelos Vieira, pelo trabalho nas análises da FCO e pelas grandes contribuições ao desenvolvimento deste projeto.

À Prof ${ }^{a}$ Marisa A. B. Regitano D'Arce, pela orientação e sugestões na parte analítica do trabalho, e pelo uso do laboratório de Óleos e Gorduras.

À Profa Maria Cristina Stolf Nogueira pela atenção durante o curso e pelas orientações na análise estatística.

Ao José Henrique Barbi, da Novus do Brasil, pelas informações, referências, e pela pronta colaboração sempre que eu precisei.

Ao Ricardo Cavalcanti Martino, pesquisador da Unidade de Tecnologia do Pescado/FIPERJ, pela amizade e pela prontidão nas análises dos ácidos graxos.

Às secretárias do Departamento de Produção Animal, Cláudia C. de Camargo e Vera Lúcia Graciano, pela atenção e carinho. 
Aos amigos da Pós-Graduação Márcia Chistina lafigliola, Juliano Benedito Gaiotto e Adriana Ayres Pedroso pela amizade e incentivo durante o curso e pela ajuda na coleta dos dados experimentais.

À Indústria Agroquímica Braido S/A, pela doação da farinha de carne e ossos.

À Guyomarc'h do Brasil, na pessoa do amigo Cláudio H. W. de Bem, pela doação dos premixes vitamínicos e minerais.

Aos funcionários do Departamento de Produção Animal, especialmente ao Alexandre, ao Chico e ao Antônio Carlos pelo suor e pelas longas horas de trabalho durante toda a fase experimental.

À todos os funcionários da Biblioteca Central, em especial às bibliotecárias Silvia Maria Zinsly e Eliana M. Garcia pelos esclarecimentos e pela revisão das referências bibliográficas.

A todos aqueles que, de alguma maneira, auxiliaram na realização deste trabalho. 


\section{SUMÁRIO}

Página

LISTA DE FIGURAS............................................................................

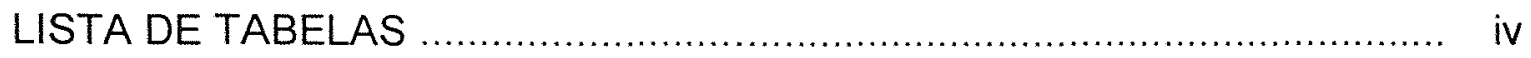

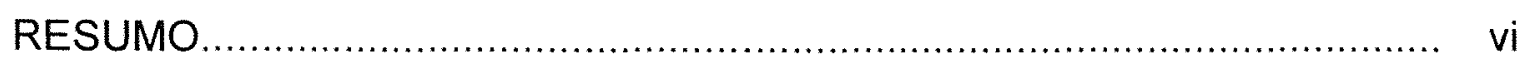

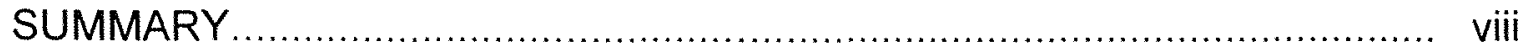

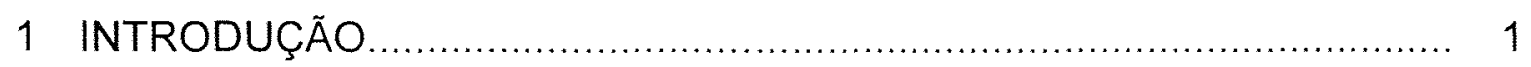

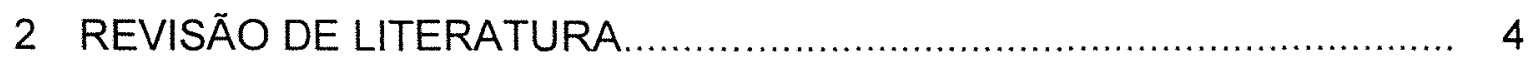

2.1 A farinha de carne e ossos na alimentação animal.............................. 4

2.2 Qualidade da proteína e digestibilidade dos aminoácidos..................... 6

2.3 A contribuição energética da FCO .................................................. 8

2.4 A rancidez nas gorduras............................................................. 9

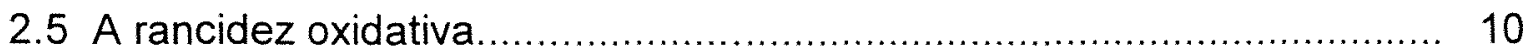

2.6 A oxidação nos tecidos vivos.......................................................... 12

2.7 As consequências da rancidez oxidativa para o organismo animal........ 13

$2.8 \mathrm{O}$ controle da rancidez oxidativa................................................. 18

2.9 Antioxidantes: tipos e modo de ação.............................................. 19

2.9.1 Os antioxidantes naturais....................................................... 19

2.9.2 Os antioxidantes sintéticos..................................................... 21

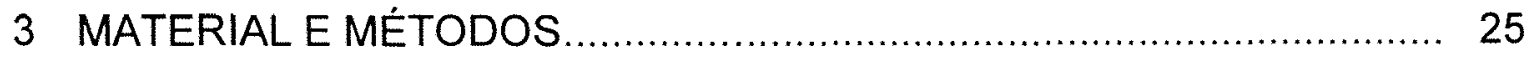

3.1 Local e período experimental.................................................... 25

3.2 Farinha de carne e ossos (FCO) ............................................... 25

3.3 Animais experimentais ........................................................ 29

3.4 Instalações, preparação e condução do experimento.......................... 29

3.5 Rações experimentais...................................................................... 31 
3.6 Tratamentos e delineamento experimental...................................... 33

3.7 Variáveis estudadas...................................................................... 33

3.8 Análise estatística..................................................................... 34

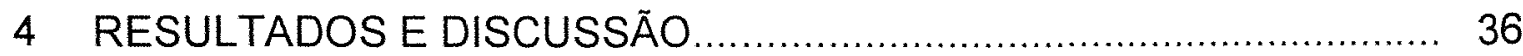

4.1 Composição e qualidade inicial da FCO ........................................ 36

4.2 Qualidade da FCO armazenada.................................................. 36

4.3 Resultados de desempenho....................................................... 46

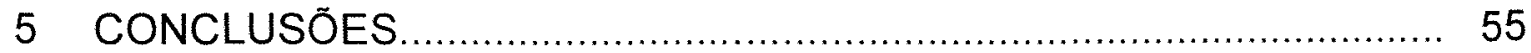

REFEREANCIAS BIBLIOGRÁFICAS.................................................... 56

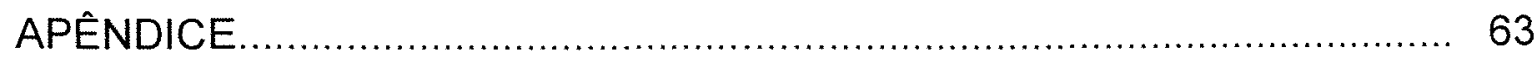




\section{LISTA DE FIGURAS}

Página

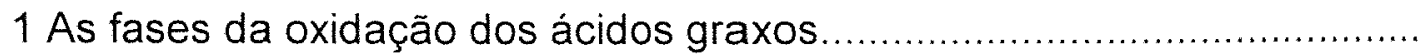

2 Ação dos antioxidantes sobre a molécula do ácido graxo

3 Índice de peróxidos (meq $/ \mathrm{kg}$ ) das amostras de FCO analisadas 


\section{LISTA DE TABELAS}

Página

1 Composição percentual média da farinha de carne e ossos..................... 9

2 As mais importantes espécies reativas do oxigênio (ROS)

produzidas no tecido animal.

3 Composição percentual e índices de qualidade da FCO ...................... 26

4 Composição dos ácidos graxos da gordura extraída da FCO ................. 27

5 Médias de máxima e mínima de temperatura e de umidade

relativa do ar coletadas durante o período de armazenamento da FCO........ 28

6 Composição percentual e niveis nutricionais calculados das rações....... 32

7 Esquema da análise da variância.................................................. 35

8 Resultados das análises semanais das amostras de FCO não tratada com BHT (CONTROLE), nas diversas datas de amostragem.......... 38

9 Resultados das análises semanais das amostras de FCO tratada com BHT no dia 31/03/99 (BHT/0), nas diversas datas de amostragem.

10 Resultados das análises semanais das amostras de FCO tratada com BHT no dia 06/04/99 (BHT/7), nas diversas datas de amostragem. 40

11 Resultados das análises semanais das amostras de FCO tratada com BHT no dia 13/04/99 (BHT/14), nas diversas datas de amostragem..... 
12 Resultados das análises semanais das amostras de FCO tratada com BHT no dia 20/04/99 (BHT/21), nas diversas datas de amostragem.....

13 Resultados das análises semanais das amostras de FCO tratada com BHT no dia 27/04/99 (BHT/28), nas diversas datas de amostragem.....

14 Resultados médios de ganho de peso (GP), consumo de ração $(C R)$, conversão alimentar (CA), mortalidade + refugagem (MR) por tratamento no período de 1 a 21 dias de idade.

15 Resultados médios de ganho de peso (GP), consumo de ração $(C R)$, conversão alimentar (CA), mortalidade + refugagem (MR) por tratamento no período de 21 a 42 dias de idade 49

16 Resultados médios de peso vivo aos 42 dias (PV), consumo de ração (CR), conversão alimentar (CA), ganho de peso diário (GPD), mortalidade + refugagem (MR) e fator de produção (FP) por tratamento no período de 1 a 42 dias de idade 


\title{
EFEITO DA ADIÇÃO DO ANTIOXIDANTE BHT E DO ARMAZENAMENTO E SOBRE A QUALIDADE DA FARINHA DE CARNE E OSSOS PARA FRANGOS DE CORTE
}

\author{
Autora: ALINE MONDINI CALIL RACANICCI \\ Orientador: Prof. Dr. JOSÉ FERNANDO MACHADO MENTEN
}

\section{RESUMO}

Atualmente, a farinha de carne e ossos (FCO) vem sendo utilizada com grande frequência nas formulações de rações para frangos de corte como fonte de fósforo, e contribuindo com cálcio, aminoácidos e energia, reduzindo consideravelmente os custos de alimentação. No entanto, a fração lipídica da FCO que contribui com grande parte da energia é muito suscetivel à rancidez oxidativa, um processo muito rápido e destrutivo, que provoca mudanças organolépticas e nutricionais da farinha, destruindo ácidos graxos insaturados, vitaminas e outros compostos, além de representar riscos à saúde animal. Neste trabalho acompanhamos o armazenamento da FCO em uma fábrica de rações e as alterações na sua qualidade no decorrer do tempo através de análises periódicas do indice de peróxidos (IP). Procuramos avaliar também a eficácia da adição do antioxidante BHT na FCO armazenada e determinar o 
tempo máximo decorrido entre a fabricação da farinha e o seu tratamento com antioxidante, de forma que este ainda forneça a proteção necessária. Utilizamos um lote de $400 \mathrm{~kg}$ de FCO adquirido de um fornecedor local, que foi armazenado durante 10 semanas numa fábrica de rações em um ambiente constantemente monitorado. Este lote foi dividido em 6 sub-lotes, sendo um não tratado (CONTROLE) e os outros cinco tratados com antioxidante BHT (500 ppm) em diferentes tempos de armazenamento (adição do BHT no dia 0: BHT/0, no dia 7: BHT/7, no dia 14: BHT/14, no dia 21: BHT/21 e no dia 28: BHT/28). A partir da $4^{\text {a }}$ semana de armazenamento, foi conduzido um experimento com frangos de corte que foram alimentados com rações contendo as FCO armazenadas. As rações, à base de milho e farelo de soja e contendo cerca de $4 \%$ de $\mathrm{FCO}$, foram fornecidas a 1.440 pintos de um dia de idade durante 42 dias. Os animais foram distribuídos num delineamento em blocos casualizados, com 6 tratamentos e 6 repetições. Os resultados obtidos para peso vivo $(P V)$, ganho de peso $(\mathrm{GP})$, consumo de ração $(\mathrm{CR})$, conversão alimentar (CA), mortalidade + refugagem (MR) e fator de produção (FP) foram submetidos à análise da variância $e$ as médias dos tratamentos foram comparadas ao CONTROLE através do teste de Dunnet. O IP máximo encontrado na FCO armazenada foi de quase $80 \mathrm{meq} / \mathrm{kg}$ no tratamento CONTROLE. Apesar da presença desta farinha nas rações, o nível de peróxidos resultante $(0,3 \mathrm{meq} / \mathrm{kg}$ de ração) aparentemente não foi suficiente para causar prejuízos às aves. Os resultados médios de PV $(2,6 \mathrm{~kg}), \mathrm{GP}$ diário $(61,0 \mathrm{~g}), \mathrm{CR}(4,50 \mathrm{~kg}), \mathrm{CA}(1,75)$, em geral, não foram afetados pelos tratamentos $(P<0,05)$, indicando que o uso da FCO oxidada, bem como das FCO protegidas pelo BHT, não afetaram o desempenho das aves nas condições deste estudo. 


\title{
EFFECTS OF THE ADITION OF BHT AND STORAGE ON THE QUALITY OF MEAT AND BONE MEAL FOR BROILER CHICKENS
}

\author{
Author: ALINE MONDINI CALIL RACANICCI \\ Adviser: Prof. Dr. JOSÉ FERNANDO MACHADO MENTEN
}

\section{SUMMARY}

Meat and bone meal (MBM) is an important animal by-product used as a feed ingredient in poultry diets because it is a source of calcium, phosphorus, essential amino acids and energy. However the lipid fraction of MBM is very susceptible to oxidation because it contains hight amounts of unsaturated fatty acids, especially oleic and linoleic acids. The objectives of this study were to assess the variation in quality of MBM during an extended storage period (10 weeks), evaluate the effects of the antioxidant BHT on MBM and the performance of broilers fed diets containing these MBM. A fresly produced batch of commercial MBM was divided into six portions: one was stored with no BHT added and the others were treated with $500 \mathrm{mg} \mathrm{BHT} / \mathrm{kg}$ at different times (day 0 , $7,14,21$ and 28 begining on the day of production). The quality of MBM was 
evaluated through weekely samplings, and peroxide value (PV) was the main parameter analysed. After that, a feed trial was carried out using 1,440 male Ross $X$ Ross day-old chicks raised in floor pens in an experiment with six treatments and six replicates. Treatments were CONTROL (diet containing MBM without $\mathrm{BHT}$ ), BHT/0, BHT/7, BHT/14, BHT/21 and BHT/28 (diets with MBM treated with BHT on d $0,7,14,21$ and 28). The birds were fed ad libitum cornsoy diets formulated to contain aproximately 4\% MBM and $22.0,21.0$ and $19 \%$ $\mathrm{CP}$ and $3,000,3,050$ and 3,100 kcal ME/kg in the 1-21 d, 21-35 d and 35-42 d periods, respectively. Results of $42 \mathrm{~d}$ liveweight (LW), feed intake (FI), feed:gain ratio $(F / G)$ and mortality + culling $(M C)$ in the overall period were submitted to analysis of variance; treatment means were compared to CONTROL using Dunnet's test at $5 \%$ probability level. There was an increase in the PV of untreated MBM during the storage period, reaching levels above the accepted by industry $(10 \mathrm{meq} / \mathrm{kg})$ after the second week. When BHT was added up to $7 \mathrm{~d}$ of storage, it was effective in preserving the quality of MBM and PV mantained at zero until the end of the experiment. When the oxidation process was already started (BHT/14 through BHT/28), the addition of BHT did not prevent PV from increasing. Although rancidity was observed in MBM after storage, the levels of PV found (maximum 80 meq $/ \mathrm{kg}$ ) did not adversely affect bird performance. The results indicated that, although there was a significant difference $(P<.05)$ on LW and $\mathrm{FI}$ of $\mathrm{BHT} / 28$ relative to CONTROL, in general it appears that the addition of the antioxidant BHT in the MBM used in this study did not affected the performance of the broilers. The additions of $500 \mathrm{mg} \mathrm{BHT/ \textrm {kg }}$ in MBM was effective in preventing oxidative rancidity when done on the fresh product or after seven days. Under the conditions of this study, MBM with no antioxidant added maintained PV below the maximum allowed $(10 \mathrm{meq} / \mathrm{kg})$ for one week only. MBM with PV around $80 \mathrm{meq} / \mathrm{kg}$, when added to broiler diets at rate of aproximately $4 \%$ and fed from 0 to 42 days, did not appear to be detrimental to the performance of the birds. 


\section{INTRODUÇÃO}

Nas últimas décadas, alguns fatores foram os principais responsáveis pelo crescente aumento na capacidade da produção avícola mundial. Dentre eles, destacam-se o melhoramento genético das linhagens, as condições de manejo, sanidade e ambiente aplicadas atualmente na avicultura.

Em consequência disso, para que a capacidade máxima de desempenho animal seja atingida, um enfoque especial deve ser dado a nutrição. Como é através da ração que os nutrientes serão fornecidos aos animais, o seu custo deve ser compatível com os resultados de desempenho e econômicos pretendidos, já que a alimentação representa, para frangos de corte, cerca de 65 a $70 \%$ do custo total de produção.

Para tanto, é necessário buscar ingredientes que sejam boas alternativas para a redução deste custo; no entanto, devemos estar sempre atentos à qualidade real destes ingredientes, para que possamos atingir os objetivos propostos com segurança.

A farinha de carne e ossos (FCO) é um ingrediente de origem animal que vem sendo usado com muita frequência na nutrição de frangos de corte, principalmente por ser vantajoso economicamente e por se tratar de um produto de alto valor nutritivo, representando uma alternativa muito interessante às fontes convencionais de fósforo, cálcio, aminoácidos e energia.

No entanto, as condiçōes de processamento (tipo, temperatura e pressão utilizadas no cozimento e secagem) das FCOs, bem como a composição e a qualidade inicial das matérias-primas utilizadas na sua fabricação variam muito 
entre os fabricantes. Isso constitui a maior fonte de variação que influencia a qualidade do produto final e também representa uma desvantagem para a utilização da FCO como ingrediente de rações animais.

Além disso, o conteúdo energético da FCO vem principalmente da gordura contida neste produto. Em geral, quase metade desta gordura é composta por ácidos graxos insaturados, principalmente os ácidos oléico e linoléico, que são os mais propensos a desenvolver rancidez oxidativa.

A rancidez oxidativa é um processo que envolve o oxigênio e a fração lipídica presente nos alimentos ou componente dos tecidos vivos em uma série de reações onde se formam diversos produtos intermediários, como os peróxidos; e produtos finais, como cetonas, aldeídos e ácidos orgânicos. Estes últimos são responsáveis pelas alterações de odor e sabor característicos do alimento oxidado.

Radicais livres e outros produtos intermediários da oxidação são potencialmente tóxicos se forem ingeridos ou produzidos nos tecidos animais. $O$ estresse oxidativo gerado pode provocar sérios danos ao organismo e grandes prejuizos à produção de carne.

Para viabilizar o uso de fontes energéticas nas rações de frangos de corte, evitando a ocorrência de rancidez, tem-se tornado cada vez mais comum a adição de antioxidantes nos ingredientes ou às rações.

Atualmente existe uma grande variedade de antioxidantes sintéticos disponíveis no mercado, cada um com suas caracteristicas e indicações próprias, mas é de consenso geral que a adição do antioxidante deve ser efetuada o quanto antes, para que este seja mais efetivo e seguro na prevenção da rancidez.

No caso da FCO, recomenda-se que o antioxidante seja adicionado no momento da produção, ou seja, na fábrica. Aliás, é comum encontrarmos produtores de rações que resistem muito em adquirir matérias-primas, como a FCO, que não sejam preservadas com antioxidantes. Caso isso não seja possivel, é recomendável evitar o armazenamento da FCO, ou de qualquer 
outro produto suscetivel à rancidez, por um período de tempo muito longo, maior do que duas semanas. Recomenda-se também evitar a utilização de produtos contendo niveis de peróxidos maiores do que o máximo estabelecido oficialmente para cada matéria-prima.

Este trabalho foi desenvolvido visando avaliar a qualidade inicial de uma FCO e acompanhar as variações de qualidade ocorridas neste produto durante o armazenamento prolongado, em condiçōes normais de campo.

Estudamos a eficácia da adição do antioxidante BHT ao produto e se a sua adição traz benefícios quando efetuada depois de a FCO ser produzida ou mesmo armazenada. Determinamos também quanto tempo a FCO permaneceu armazenada e em condições de ser utilizada para a produção de rações, sem a adição do antioxidante.

Finalmente, através da avaliação do desempenho de frangos de corte alimentados com rações contendo a FCO preservada ou não com antioxidante, objetivamos esclarecer melhor os critérios de avaliação da qualidade deste ingrediente e estabelecer com maior precisão e segurança os parâmetros para o seu uso. 


\section{REVISÃO DE LITERATURA}

\subsection{A farinha de carne e ossos na alimentação animal}

Em decorrência da grande expansão da avicultura de corte nos últimos anos, e visando a produção de rações mais adequadamente balanceadas e de menor custo, têm-se pesquisado um grande número de matérias-primas que constituam boas alternativas aos ingredientes normalmente utilizados.

A farinha de carne e ossos (FCO) é o principal subproduto de origem animal utilizado nas rações de aves como fonte alternativa de proteína e de fósforo, e é definida como:

"Produzida em graxarias e frigorificos a partir de ossos e resíduos de tecidos animais, após a desossa completa da carcaça de bovinos. Não deve conter cascos, chifres, pêlos, conteúdo estomacal, sangue e outras matérias estranhas. São especificados três tipos: $38 \%, 45 \%$ e $50 \%$ de proteína bruta" (Compêndio, 1998, p.27).

As principais vantagens do uso da FCO nas rações, além do aspecto econômico, estão relacionadas com o seu conteúdo de proteina, cálcio e fósforo (Andriguetto et al., 1986; Scott et al., 1982).

A FCO é considerada uma fonte adequada de proteína, pois contém quantidade suficiente de lisina para suplementar a proteina fornecida pelos 
grãos, mas tem concentrações relativamente baixas de metionina e cistina (Scott et al., 1982).

Contudo, o que limita a quantidade da farinha a ser incluida nas rações é - nível de fósforo da dieta, uma vez que a FCO apresenta altos níveis deste nutriente (cerca de 4 a $6 \%$ de fósforo). Além disso, tanto a composição quanto a qualidade nutricional da FCO podem ser muito variáveis, dependendo da composição da matéria original e das condições de processamento e secagem. Segundo Scott et al. (1982), são estes dois fatores associados que limitam a utilização da FCO a um máximo de 7,5 a $10 \%$ da dieta.

Dois experimentos foram conduzidos por Sell (1996) alimentando perus com dietas contendo $0 ; 3 ; 6,5$ e 10\% de FCO de 1 a 42 dias, e de 42 dias até 119 dias de idade, respectivamente. O autor obteve excelentes resultados de peso vivo e de conversão alimentar e concluiu que a FCO pode ser usada nas rações com sucesso até o nível de inclusão de $10 \%$ nas dietas, desde que a formulação leve em conta a composição da farinha utilizada. Além disso, verificou também grandes vantagens econômicas na sua utilização, uma vez que o aumento da inclusão da FCO nas dietas provocou uma consequente redução nas participações das fontes de fósforo (fosfato bicálcico) e de energia (gorduras animal e vegetal), ingredientes de custo elevado.

Em relação à substituição do fósforo nas dietas, Waldroup \& Adams (1994) não encontraram diferenças significativas na disponibilidade biológica do fósforo de diversos subprodutos de abatedouros produzidos a partir de aves, suínos e bovinos, em comparação com o uso do fosfato bicálcico. Contudo, enfatizaram a necessidade de um bom programa de controle de qualidade das farinhas animais utilizadas, com a finalidade de monitorar as variações de composição e, constantemente, ajustar as matrizes nutricionais utilizadas para formulação das rações. 


\subsection{Qualidade da proteína e digestibilidade dos aminoácidos}

As variações na qualidade e na composição nutricional das FCO estão relacionadas diretamente com a matéria-prima utilizada e com as condições de processamento, fator este que pode também influir na disponibilidade dos nutrientes da farinha (Dolz \& De Blas, 1992; Parsons et al.,1997).

Em experimentos in vivo e in vitro, Parsons et al. (1997) compararam 14 tipos de FCO e verificaram que as variações na qualidade da proteina são decorrentes tanto da concentração, como da digestibilidade dos aminoácidos nas diferentes farinhas. De maneira geral, a relação de eficiência protéica (PER) estava relacionada positivamente com o teor de proteína bruta, com a digestibilidade dos aminoácidos sulfurados e com a disponibilidade biológica da lisina nas amostras estudadas. Contudo, uma correlação negativa foi verificada para o teor de matéria mineral, sugerindo este como sendo um bom parâmetro para a avaliação da qualidade da proteína da FCO em função dos reflexos da presença de ossos e de colágeno (considerado uma proteína de baixa qualidade) neste produto.

Apesar da importância da qualidade da proteína para o uso da FCO nas rações animais, a ordem dos aminoácidos limitantes na proteína da FCO para aves não é muito afetada por este parâmetro, de acordo com Wang, $X$. et al. (1997). Em uma série de estudos de adição e deleção de aminoácidos, estes autores determinaram que os aminoácidos mais limitantes, em primeiro lugar são o triptofano e os aminoácidos sulfurados. Em seguida, estão os demais aminoácidos: $2^{\circ}$ ) treonina, $3^{\circ}$ ) isoleucina e fenilalanina + tirosina, $4^{\circ}$ ) metionina, $5^{\circ}$ ) lisina e $6^{\circ}$ ) valina e histidina. Como o triptofano e os aminoácidos sulfurados são mais limitantes na proteína da FCO do que quaisquer outros, nenhuma alteração na qualidade desta proteína ou na digestibilidade dos aminoácidos, decorrente do processamento ou da composição da matéria original, foi suficiente para modificar esta ordem. 
As grandes variações que podem ser verificadas na digestibilidade e na disponibilidade biológica dos aminoácidos da FCO geralmente decorrem das condições de processamento a que a farinha é submetida, especialmente de dois fatores: tempo e temperatura de processamento (cozimento e/ou secagem), segundo Wang \& Parsons (1998a,c). Estes autores não encontraram nenhuma influência das condições de processamento sobre o conteúdo de matéria mineral ou proteína, ou sobre o conteúdo de aminoácidos das farinhas estudadas, mas verificaram efeito pronunciado sobre a digestibilidade verdadeira dos aminoácidos. Em geral, as menores temperaturas de processamento aplicadas (96 a $132{ }^{\circ} \mathrm{C}$ ) resultaram em maiores valores de digestibilidade e as maiores temperaturas $\left(110\right.$ a $\left.152{ }^{\circ} \mathrm{C}\right)$, em menores valores de digestibilidade, sendo o maior efeito sobre a cistina. Discordando do que normalmente é aceito, a quase totalidade da lisina e da metionina digestiveis estava disponível para o metabolismo e a síntese protéica, no entanto, somente de 20 a $50 \%$ da cistina digestivel da FCO de baixa ou de alta qualidade estava disponivel para o crescimento animal.

$O$ efeito do processamento sobre a digestibilidade da cistina não era esperado e a razão da sua ocorrência ainda é desconhecida, mas os autores sugerem a possibilidade da cistina estar sendo convertida em lantionina ou lisinoalanina pela ação do calor. Normalmente aceita-se que o maior efeito do excesso de temperatura ou superprocessamento se dá sobre a disponibilidade da lisina (Batterham et al., 1986) devido às reações de Maillard, no entanto, o efeito da temperatura sobre a lisina naquele estudo foi menor para FCO do que para farelos de oleaginosas provavelmente devido ao menor conteúdo de carboidratos e de açúcares redutores da FCO.

Contudo, de nada vale discutirmos a digestibilidade dos aminoácidos se as rações forem formuladas a partir de dados de aminoácidos totais, como ainda é uma prática bastante comum na avicultura brasileira. Confirmando esta prerrogativa, Wang \& Parsons (1998b) avaliaram o desempenho das aves alimentadas com dietas contendo FCO de baixa ou de alta qualidade 
formuladas com base nos aminoácidos totais ou digestiveis. De uma maneira geral, os resultados demonstraram que, dietas contendo FCO formuladas com base nos aminoácidos digestíveis promoveram melhor desempenho do que as formuladas com base nos aminoácidos totais, especialmente quando continham FCO de baixa qualidade. Além disso, os autores constataram também que o uso de FCO de baixa qualidade exigiu uma suplementação adicional de aminoácidos para que as aves obtivessem o máximo crescimento, comprovando a importância da avaliação constante e o mais precisa possivel da composição e da qualidade das matérias-primas utilizadas nas rações, além do ajuste da formulação, principalmente quando fazemos uso de ingredientes muito variáveis.

\subsection{A contribuição energética da FCO}

Apesar das variações constantemente verificadas nas FCO, Dolz \& De Blas (1992) determinaram a energia metabolizável corrigida pelo balanço de nitrogênio $\left(E M_{n}\right)$ de amostras de FCO em diferentes níveis de substituição à ração basal. Estes autores relataram que as melhores estimativas de energia metabolizável aparente (EMA) e verdadeira (EMV) foram obtidas com base nas avaliações prévias dos teores de proteina bruta (PB) e extrato etéreo (EE) das amostras, considerando que estes nutrientes ( $P B$ e EE) são os principais responsáveis pelo conteúdo energético da FCO.

A composição da gordura da FCO (Tabela 1) apresenta quantidades expressivas de ácidos graxos insaturados, sendo que praticamente $50 \%$ dos ácidos graxos consiste dos ácidos oléico e linoléico. É por este motivo que a FCO é considerada um produto muito suscetivel às reações de rancidez (Maynard et al., 1984; Quiñones, 1995; Scott et al., 1982; Valenzuela \& Nieto, 1995). 
Tabela 1: Composição percentual média da farinha de carne e ossos.

\begin{tabular}{|c|c|c|c|c|c|c|c|c|}
\hline \multirow{2}{*}{ MS } & \multirow{2}{*}{ EE } & \multicolumn{6}{|c|}{ Ácidos Graxos ${ }^{1}$ ( $\%$ do EE) } & \multirow[t]{2}{*}{ Referências } \\
\hline & & $C_{14: 0}$ & $C_{16: 0}$ & $C_{16: 1}$ & $C_{18: 0}$ & $C_{18: 1}$ & $C_{18: 2}$ & \\
\hline 95,0 & 12,0 & - & 28,0 & - & 17,0 & 46,3 & 4,3 & Dolz \& De Blas (1992) \\
\hline \multicolumn{7}{|c|}{ Total de insaturados: } & 50,6 & \\
\hline 93 & 8,6 & 2,6 & 27,4 & 5,1 & 16,5 & 43,5 & 3,6 & NRC (1994) \\
\hline \multicolumn{7}{|c|}{ Total de insaturados: } & 52,2 & \\
\hline
\end{tabular}

\subsection{A rancidez nas gorduras}

Existem dois tipos de rancidez passiveis de ocorrer nas gorduras, a rancidez hidrolitica e a oxidativa, segundo Maynard et al. (1984) e Scott et al. (1982).

A rancidez hidrolítica é catalisada por enzimas (lipases) ou por microrganismos e consiste na hidrólise dos triglicerídeos resultando na formação de mono e diglicerídeos e ácidos graxos livres, que são responsáveis pelo odor e sabor desagradáveis no material, embora não alterem o seu valor nutritivo.

Já a rancidez oxidativa representa significativas perdas econômicas, pela destruição dos ácidos graxos insaturados, das vitaminas lipossolúveis e carotenos (Adams, 1999; Maynard et al., 1984), além do alto risco toxicológico representado pelos produtos secundários formados no decorrer do processo (Valenzuela \& Nieto, 1995). 
O processo de rancidez oxidativa ou peroxidação lipídica é a principal causa de perdas da qualidade do alimento ou da ração, afetando o seu sabor, aroma, cor e textura, além de resultar em um sério decréscimo no seu valor nutritivo (Scott et al., 1982).

\subsection{A rancidez oxidativa}

A oxidação é um processo inerente ao organismo animal e é extremamente importante no metabolismo normal dos animais, uma vez que, através da oxidação os nutrientes provenientes dos alimentos são oxidados com a finalidade de gerar calor, produzir energia para os processos metabólicos e transformar nutrientes em tecido corporal (Adams, 1999).

Enquanto o oxigênio é essencial ao metabolismo, sua presença também é perigosa em função da possibilidade da ocorrência de reações de oxidação, um processo de dificil controle, que pode causar a destruição de componentes importantes dos alimentos, além de danos às estruturas celulares e aos tecidos animais (Adams, 1999).

Existem compostos que reagem espontaneamente com o oxigênio e sofrem deterioração durante o processo de oxidação, entre eles estão os óleos e as gorduras presentes nos alimentos ou adicionadas às rações, as vitaminas lipossolúveis, além de pigmentos carotenóides (Adams, 1999). Em função da sua estrutura química, os ácidos graxos insaturados, que contém duplas ligações nas cadeias de carbono, são mais facilmente oxidados (Robey \& Shermer, 1994).

O processo de oxidação se inicia na ligação carbono-hidrogênio adjacente à dupla ligação da cadeia de carbono, e pode ser catalisado por um grande número de fatores, especialmente fatores ambientais (umidade, temperatura, luz e oxigênio), presença de metais (cobre, ferro e manganês) e de enzimas (Adams, 1999). Trata-se de um processo bastante complexo e composto por três fases: iniciação, propagação e terminação. 
Nas fases de iniciação e propagação a presença de radicais livres, que são moléculas altamente reativas, é decisiva (Adams, 1999). Para dar início à rancidez oxidativa, o oxigênio atmosférico precisa estar em uma forma ativa para atacar as insaturações dos ácidos graxos, pois a forma molecular $\left(\mathrm{O}_{2}\right)$ é quimicamente pouco reativa (Valenzuela \& Nieto, 1995).

A estrutura química do oxigênio permite a ele receber e perder elétrons, transformando a sua molécula em radicais livres de alta reatividade química. Os radicais livres de maior importância e reatividade química se formam a partir de reduções consecutivas do oxigênio molecular e são o radical superóxido $\left(\mathrm{O}_{2} \bullet\right)$ e o radical hidroxila (HO•), segundo Valenzuela \& Nieto (1995). São estes radicais livres que podem atacar a estrutura dos ácidos graxos de um lipidio iniciando a rancidez oxidativa.

É na ativação das moléculas de oxigênio atmosférico que alguns metais em estado livre (ions), ligados a estruturas inorgânicas (complexos metálicos) ou orgânicas (ligado a uma proteina, ex.: o ferro ligado à hemoglobina) agem como catalisadores facilitados pela temperatura, luz e concentração de oxigênio. Além disso, a presença de microrganismos, através do efeito de algumas enzimas e de outras moléculas sobre a ativação do oxigênio, também facilita a iniciação da rancidez nas gorduras. Portanto, os dois tipos de rancidez (hidrolítica e oxidativa) podem ocorrer ao mesmo tempo em um mesmo material (Quiñones, 1995; Valenzuela \& Nieto, 1995).

Após a ação do oxigênio ativo sobre 0 ácido graxo insaturado, este se converte em um radical livre de alta reatividade que pode então ser atacado pelo oxigênio atmosférico, gerando produtos intermediários como os peróxidos, pela adição do oxigênio ao ácido graxo (Figura 1).

Para a estabilização dos produtos intermediários, estes retiram hidrogênio de outro ácidos graxos ainda não atacados pelos radicais livres de oxigênio transformando-os em radicais livres de ácidos graxos. Esta etapa é chamada de propagação e, pelas características descritas acima, é muito rápida e autocatalitica, pois não exige mais o oxigênio ativo para a 
decomposição do lipidio. Durante esta fase, quanto mais insaturado for o lipídio, mais rápido é o avanço da rancidez oxidativa.

Durante a fase de terminação ocorre a combinação entre diversos tipos de radicais livres, gerando produtos finais estáveis, principalmente os hidrocarbonos, aldeídos, cetonas, álcoois e ácidos orgânicos. Estes produtos conferem odor e sabor de ranço, características impalatáveis do alimento oxidado (Adams, 1999; Quiñones, 1995; Valenzuela \& Nieto, 1995).

Figura 1- As fases da oxidação dos ácidos graxos.

\begin{tabular}{|c|c|}
\hline INICIAÇÃO & $\mathrm{RH}+\mathrm{OH} \bullet \longrightarrow$ \\
\hline PROPAGAÇÃO & $\mathrm{R} \cdot+\mathrm{O}_{2} \longrightarrow \mathrm{ROO} \cdot$ (peróxido) \\
\hline $\mathrm{ROO} \bullet+$ & $\mathrm{ROOH}$ (hidroperóxido) $+\mathrm{R}$ - \\
\hline TERMINAÇÃO & $\mathrm{ROO} \cdot+\mathrm{ROO} \longrightarrow$ produtos finais estáveis \\
\hline
\end{tabular}

Fonte: adaptado de Adams (1999).

\subsection{A oxidação nos tecidos vivos}

Assim como no ambiente, durante o metabolismo normal do oxigênio nos tecidos vivos também são produzidas formas e compostos muito mais reativos que o oxigênio molecular $\left(\mathrm{O}_{2}\right)$, como pode ser visto na Tabela 2. Estes compostos são chamados de espécies reativas de oxigênio (ROS - Reactive Oxygen Species). 
Tabela 2: As mais importantes espécies reativas do oxigênio (ROS) produzidas no tecido animal.

\begin{tabular}{lcc}
\hline Moléculas não radicais & Oxigênio molecular & $\mathrm{O}_{2}$ \\
& Peróxido de hidrogênio & $\mathrm{H}_{2} \mathrm{O}_{2}$ \\
Radicais livres & Superóxido & $\mathrm{O}_{2} \bullet$ \\
& Hidroxila & $\mathrm{HO} \bullet$ \\
\hline
\end{tabular}

Fonte: adaptado de Adams (1999)

Segundo Adams (1999), alguns compostos são formados durante o metabolismo aeróbico normal das células vivas, como é o caso do radical superóxido $\left(\mathrm{O}_{2} \bullet\right)$, que é formado pela adição de um elétron extra ao oxigênio molecular $\left(\mathrm{O}_{2}\right)$. Radicais superóxido são formados in vivo através da descarga de elétrons proveniente da cadeia respiratória mitocondrial, que provoca a redução direta do oxigênio diretamente. As células que realizam fagocitose também são grandes geradoras de radicais livres de oxigênio no organismo. No entanto, o radical hidroxila (HO•) é o mais importante iniciador de oxidação no corpo animal, provocando prejuizos a uma série de moléculas presentes nos tecidos animais, incluindo proteinas, compostos sulfurados e ácidos nucléicos.

\subsection{As consequências da rancidez oxidativa para o organismo animal}

A peroxidação lipídica, se não for rapidamente bloqueada, pode provocar sérios danos ao material genético das células e em muitas proteínas importantes, promovendo o aparecimento de doenças. Diversos tipos de sistemas de defesa com ação antioxidante estão envolvidos neste processo 
com a finalidade de limitar a exposição dos tecidos a estes radicais livres e aos danos que eles possam causar (Adams, 1999).

O consumo de alimento oxidado representa um risco enorme para a saúde, tanto para os humanos, como para os animais. Os humanos normalmente evitam o consumo de gorduras oxidadas em função do odor de ranço, no entanto, os animais, principalmente as aves, muitas vezes não conseguem evitá-los, já que não têm outra opção de alimentação (Adams, 1999).

Em decorrência do consumo do alimento oxidado e da destruição de certos nutrientes durante o processo de oxidação, principalmente vitamina $\mathrm{E} \mathrm{e}$ ácidos graxos essenciais, quadros de oxidação severa têm sido associados com o estresse oxidativo, como por exemplo, encefalomalácia, diátese exudativa, distrofia muscular, necrose dos tecidos de vários órgãos, além da baixa fertilidade e taxa de eclosão (Cabel et al., 1988).

A deficiência de ácidos graxos essenciais em aves pode causar uma série de problemas, dentre eles a redução no crescimento, aumento no consumo de água, problemas reprodutivos, aumento no tamanho do fígado e alterações na sua composição lipídica (sindrome do fígado gordo) e menor resistência a doenças (Balnave, 1970; Watkins, 1991).

Friedman \& Sklan (1997) verificaram um decréscimo acentuado na taxa de crescimento de perus associado com a menor concentração dos ácidos graxos do grupo $\mathrm{C}_{18}$ na dieta, e concluíram que esta redução do crescimento decorreu do fornecimento marginal de ácidos graxos essenciais.

Além disso, a maioria dos produtos finais da oxidação, como aldeídos e cetonas, devido a sua natureza hidrofilica e seu baixo peso molecular são facilmente absorvidos e levados pela corrente sangüínea até órgãos internos, onde promovem a oxidação lipídica in vivo (Adams, 1999). Estes produtos secundários podem ser incorporados às membranas celulares dos tecidos hepático e adiposo, provocando uma série de alterações na estrutura da membrana celular, levando a mudanças na permeabilidade, viscosidade e 
atividade secretória da membrana e na atividade de enzimas associadas à membrana (Robey \& Shermer, 1994).

A ingestão de radicais livres provenientes da gordura oxidada presente nos alimentos pode resultar numa redução da concentração de $\alpha$-tocoferol dos tecidos e, consequentemente, numa menor estabilidade destes tecidos (Asghar et al., 1989; Lin et al., 1989). A redução na quantidade do $\alpha$-tocoferol presente nas membranas sub-celulares decorrente do consumo de gordura oxidada é resultado do seu uso na proteção destas membranas contra o ataque dos radicais livres originários da gordura. A presença de óleo oxidado na ração de frangos de corte torna os lipídios da membrana celular muito suscetiveis à peroxidação, o que está intimamente ligado à estabilidade da carne durante o armazenamento (Asghar et al., 1989).

A carne de aves é considerada a carne mais propensa a desenvolver rancidez oxidativa, quando comparada com as carnes vermelhas. Isto devido ao seu alto conteúdo de fosfolipídios, já que esta fração é a que mais contribui para o desenvolvimento da rancidez da carne. Os fosfolipídios são compostos por uma grande quantidade de ácidos graxos poliinsaturados e são responsáveis por $90 \%$ da rancidez, medida em malonaldeídos, da fração lipidica da carne de aves (McKnight, 1996).

A composição dos ácidos graxos da fração fosfolipidica da membrana varia muito pouco, já que o organismo tem a necessidade de manter as suas características físicas e de permeabilidade. Sanz et al. (1999) estudaram o efeito de diferentes perfis de ácidos graxos da dieta (saturados e insaturados) em relação à composição da gordura abdominal e intramuscular, sendo esta última dividida em duas frações: fosfolipídios e triglicerídeos. Os autores confirmaram que as maiores influências ocorreram no perfil de ácidos graxos da gordura abdominal e dos trigliceridios da gordura intramuscular, enquanto que os fosfolipídios da gordura intramuscular apresentaram menor variação. O uso de maiores quantidades de ácidos graxos poliinsaturados, especialmente o ácido linoléico ( $C_{18: 2}$ ) na ração, levou a um ponto de fusão mais baixo, afetando 
a sua consistência, e aumentando a suscetibilidade desta gordura à oxidação lipídica, o que pode causar uma série de problemas no processamento e armazenamento desta carne.

$O$ efeito tóxico da presença de alimentos oxidados na dieta e dos produtos secundários da oxidação nas células foi demonstrado por Dibner et al. (1996) através da coloração de células do epitélio do intestino do fígado para observação da proliferação celular. Nos animais alimentados com gordura oxidada houve uma acentuada redução no tempo de vida das células e aumento da renovação celular, levando a um menor aproveitamento dos alimentos, um aumento na demanda energética e, consequentemente, um aumento na exigência de mantença destes animais. Se aliarmos a isso a provável redução do conteúdo energético do alimento oxidado, podemos compreender 0 decréscimo no desempenho normalmente verificado nos animais submetidos a estresse oxidativo (Cabel et al., 1988; Dibner et al., 1996; Engberg et al., 1996; Lin et al., 1989; Waldroup et al., 1960).

Há indicativos que o consumo de gorduras oxidadas também está ligado à diminuição da resistência dos animais a doenças, uma vez que muitas das funções de proteção exercidas pelas células do sistema imune dependem da fluidez das membranas fosfolipidicas destas células. A perda da fluidez tem sido relacionada diretamente com a menor capacidade dos linfócitos em responder aos desafios (Adams, 1999) e com a inibição da produção de anticorpos (Friedman \& Sklan, 1997).

A proteção imune contra os microrganismos que vivem normalmente no intestino dos animais ou que são carregados juntamente com o alimento envolve também a secreção de IgA no intestino (Dibner et al., 1996). Observou-se uma alteração no padrão de distribuição do $\lg A$ livre no intestino de aves alimentadas com alimentos oxidado. A sintese de $\lg A$ pelas células se manteve normal, mas o IgA não permaneceu e nem se acumulou no tecido, como deveria ocorrer. O resultado destas alterações pode ser uma menor 
eficácia do sistema imune associado ao intestino e, consequentemente, uma maior possibilidade de ocorrência de infeções oportunistas.

Quando o sistema de defesa do organismo animal está funcionando inadequadamente devido a presença de quantidades insuficientes de substâncias antioxidantes (baixo consumo ou absorção) ou devido a falta de enzimas necessárias para destruir os radicais livres de oxigênio e reparar os danos causados por eles, o organismo animal se torna mais vulnerável a ação destes radicais livres, levando a um acúmulo destes compostos. Este acúmulo de radicais livres, também chamado de estresse oxidativo, vem sendo considerado o principal responsável por uma série de doenças e sindromes verificadas em humanos e animais. Em aves destacamos a ascite, a síndrome hemorrágica do fígado gordo e a encefalomalácia (Adams, 1999).

Analisando a microflora do intestino de aves alimentadas com gordura fresca e oxidada, Robey \& Shermer (1994) observaram alterações na população de $E$. coli e Lactobacilli no intestino das aves sob estresse oxidativo. A multiplicação de Lactobacilli é inibida pela presença de peróxidos, resultando num decréscimo temporário na população desta bactéria e um aumento na população de E.coli. Temos que considerar ainda que os produtos da oxidação são altamente reativos e capazes de danificar o tecido gastrointestinal com o qual estão em contato, podendo provocar uma expansão da população patogênica em um ambiente propenso ao seu crescimento, o que é potencialmente perigoso.

Robey \& Shermer (1994) verificaram também modificações na função intestinal, ou seja, na absorção dos nutrientes. As aves alimentadas com a inclusão de gordura oxidada na dieta tiveram a capacidade de absorção de glicose (O-metil-glicose, um análogo não metabolizável da glicose) aumentada em resposta ao déficit de energia gerado pelo menor fornecimento de energia da gordura oxidada, ou talvez esse aumento na absorção indique uma maior necessidade de energia das aves que se encontram sob condições de estresse oxidativo. Estas alterações na absorção da glicose pelo intestino devem ser 
reações do organismo às mudanças no metabolismo de carboidratos do fígado, explicam os autores, uma vez que a absorção de produtos secundários da oxidação tem sido relacionada com o decréscimo da atividade do ciclo do ácido cítrico e com o esgotamento do NADPH e de outros compostos de alta energia. Contudo, nesse estudo, a capacidade de absorção da L-metionina não foi afetada pelas dietas, o que indica que o efeito do estresse oxidativo no transporte da glicose representa uma necessidade de energia somente, e não um completo comprometimento do transporte ou da absorção dos nutrientes como um todo.

\subsection{O controle da rancidez oxidativa}

Sendo a oxidação dos ácidos graxos e fosfolipídios um processo tão destrutivo, ao longo do tempo os animais desenvolveram estratégias para prevenir a oxidação do conteúdo celular. Contudo, se a carga de radicais livres exceder a capacidade do sistema de defesa antioxidante do organismo, irão ocorrer danos às células e aos tecidos. A eficiência deste sistema de defesa depende, em parte, do consumo de quantidade suficiente de alimentos que contenham compostos de ação antioxidante (Adams, 1999).

Os antioxidantes são substâncias que estão presentes em quantidades muito menores que o substrato oxidável, e retardam ou previnem a sua oxidação (Adams, 1999). Os antioxidantes agem eliminando os radicais livres do organismo, finalizando a sequência de propagação e dissipando a energia reativa através do anel aromático da sua estrutura (Robey, 1994).

Segundo Adams (1999), quando se pensa em prevenir ou controlar a rancidez oxidativa, a etapa de iniciação é muito importante, pois o tempo necessário para o seu desenvolvimento é variável conforme o perfil de ácidos graxos do produto e as condições de armazenamento (tipo de embalagem e permeabilidade ao oxigênio, presença de metais, umidade, luz e temperatura). 


\subsection{Antioxidantes: tipos e modo de ação}

Os antioxidantes podem ser de origem natural ou sintética, e o seu modo de ação nas reações de oxidação pode ser através da quebra da cadeia de reações, eliminando o oxigênio do meio ou interrompendo a fase de iniciação (Adams, 1999).

Os antioxidantes de quebra de cadeia ou antioxidantes primários são compostos que interceptam os radicais livres envolvidos no processo oxidativo. São formados radicais livres do antioxidante, que são mais estáveis e que não têm energia suficiente para reagir com os compostos lipídicos e formar novos radicais livres, portanto, a cadeia de reações é quebrada. Fazem parte deste grupo os antioxidantes naturais, que ocorrem normalmente nos organismos animais em pequenas quantidades, são os carotenóides, flavonóides, ácido úrico, glutationa, tocoferóis e óleos essenciais; e os antioxidantes sintéticos convencionais como o BHT, BHA e o propil galato.

Os antioxidantes "eliminadores" de oxigênio são compostos que reagem diretamente com o oxigênio e removem-no do sistema. Compostos como o ácido ascórbico e o ascorbil palmitato fazem parte deste grupo.

Alguns antioxidantes agem inibindo a fase de iniciação, quelando ions de metais que catalisam as reações de oxidação. Estes compostos restringem a formação de radicais livres e de peróxidos. Os ácidos cítrico e fosfórico pertencem a este grupo e normalmente são utilizados juntamente com os antioxidantes primários (Adams, 1999).

\subsubsection{Os antioxidantes naturais}

A vitamina $E$, na forma de $\alpha$-tocoferol, é o principal antioxidante natural, e um importante componente da membrana celular e de algumas organelas. É o maior antioxidante do sangue, apesar da sua baixa concentração, que é de 
cerca de uma molécula para 2.000 moléculas de fosfolipídios da membrana (Adams, 1999).

Muitos trabalhos têm estudado a inclusão de vitamina $E$ suplementar na dieta com a finalidade de aumentar a estabilidade oxidativa da carne (Asghar et al., 1989; Bartov et al., 1997; Bartov \& Bornstein, 1981; Lin et al., 1989; McKnight, 1996). Sheldon (1997) verificou menores alterações na coloração da carne de perus e na ocorrência do odor de ranço à medida que o nivel e a duração da suplementação com vitamina $E$ aumentou. A suplementação com 200 a $400 \mathrm{mg}$ de $\alpha$-tocoferil acetato/ $\mathrm{kg}$ na dieta de frangos tende a proteger os tecidos contra os efeitos pró-oxidantes das gorduras oxidadas (Galvin et al., 1997).

Porém, uma vez iniciada a rancidez nos ácidos graxos insaturados, os produtos gerados destroem a vitamina $E$ (Maynard et al., 1984; Scott et al., 1982). Consequentemente, o uso de gordura oxidada pode levar a deficiência de vitamina $E$, mesmo em dietas com altos níveis de inclusão (Adams, 1999).

A vitamina $C$ (ácido ascórbico) é considerado um eficiente sinergista associado à vitamina $\mathrm{E}$. Sendo um antioxidante hidrossolúvel e de grande afinidade pelo oxigênio, o ácido ascórbico age diretamente na regeneração das moléculas da vitamina E. Posteriormente, o ácido ascórbico também é regenerado através da glutationa, um peptideo que pode ser prontamente oxidado ou reduzido. A glutationa promove a desintoxicação, a proteção das células contra a oxidação e mantém o balanço oxidativo celular através de interaçōes e mecanismos enzimáticos, de acordo com Wang, S. et al. (1997). Desta forma, o papel desempenhado pela glutationa na proteção das células e na regeneração do ácido ascórbico, e, consequentemente, da vitamina $E$, é considerado de fundamental importância para a manutenção da estabilidade oxidativa das células e dos tecidos (Adams, 1999). 


\subsubsection{Os antioxidantes sintéticos}

Em alguns casos, apesar do fornecimento de quantidades suficientes de nutrientes com ação antioxidante, como certas vitaminas, torna-se necessário o uso de antioxidantes sintéticos, uma vez que aqueles nutrientes podem ser destruídos no decorrer do processo (Robey \& Shermer, 1994). Há indicativos de que os antioxidantes sintéticos, além de proporcionar uma efetiva proteção do estresse oxidativo, agem poupando os antioxidantes naturais do organismo como o tocoferol (Surak et al., 1977) e a glutationa (Wang, S. et al., 1997), uma vez que tem-se observado o aumento da concentração destes compostos com a presença de antioxidantes nas dietas.

Os antioxidantes sintéticos mais comumente utilizados em matériasprimas ou em rações animais são o $\mathrm{BHT}$ (butil hidroxitolueno, $\mathrm{C}_{15} \mathrm{H}_{24} \mathrm{O}$ ), ○ $\mathrm{BHA}$ (butil hidroxianisol, $\mathrm{C}_{11} \mathrm{H}_{16} \mathrm{O}_{2}$ ) e $\circ \mathrm{ETQ}$ (etoxiquim, $\mathrm{C}_{14} \mathrm{H}_{19} \mathrm{ON}$ ) além das diferentes combinações existentes no mercado, sendo que cada uma deles tem propriedades e utilizações específicas (Jones et al. 1986; Quiñones, 1995; Valenzuela \& Nieto, 1995). Estes compostos têm estruturas semelhantes, com a presença de um anel aromático, e tanto o BHT como o etoxiquim são altamente tolerantes aos efeitos negativos do processamento dos alimentos ou rações (calor, pressão e umidade), de acordo com Robey \& Shermer (1994), podendo, portanto, serem usados para controlar as reações de oxidação em produtos de origem animal como farinhas de carne, peixe e visceras de aves, bem como preservar a qualidade das vitaminas e pigmentos nas rações comerciais.

Do ponto de vista químico, as estruturas fenólicas e polifenólicas são as mais adequadas para se comportarem como antioxidantes, pois são capazes de estabilizar um radical livre de oxigênio ou de ácido graxo através da doação de um hidrogênio (Figura 2) e de estabilizar internamente o radical livre 
originado na sua estrutura pela saída deste hidrogênio (Valenzuela \& Nieto, 1995).

Figura 2 - Ação dos antioxidantes sobre a molécula do ácido graxo .

\begin{tabular}{|llll|}
\hline $\mathrm{AH}+\ldots \mathrm{C}-\mathrm{C}-\mathrm{C}=\mathrm{C}-\mathrm{C} \ldots$ & $\mathrm{A} \cdot+\ldots \mathrm{C}-\mathrm{H}-\mathrm{C}=\mathrm{C}-\mathrm{C} \ldots$ \\
$\begin{array}{l}\text { Antioxi- } \\
\text { dante }\end{array}$ & $\begin{array}{l}\text { Radical livre } \\
\text { do ácido graxo }\end{array}$ & $\begin{array}{l}\text { Radical } \\
\text { livre do } \\
\text { antioxidante }\end{array}$ & $\begin{array}{l}\text { Molécula } \\
\text { original do } \\
\text { ácido graxo }\end{array}$ \\
\hline
\end{tabular}

Fonte: adaptado de Giese (1996).

É importante ressaltarmos que os antioxidantes são mais efetivos quando adicionados ao material durante a fase inicial da oxidação (Adams, 1999), portanto, para atingirmos o máximo efeito, recomenda-se que a adição do antioxidante seja feita o mais rápido possível no processo de produção dos alimentos ou rações. Além disso, os antioxidantes não removem os aldeídos e outros compostos tóxicos produzidos durante o processo de oxidação das gorduras, segundo Wang, S. et al. (1997)

Sabe-se que os antioxidantes controlam a oxidação lipídica de maneira efetiva, mas pouco se sabe sobre a sua capacidade em estabilizar os lipídios da carne quando são introduzidos através da dieta (Lin et al., 1989). A absorção de quantidades significativas dos antioxidantes sintéticos pelos organismos animais é muito questionável, de acordo com Wang, S. et al. (1997); no entanto, analisando as concentrações de BHA e BHT em frangos de corte alimentados com rações contendo óleo de girassol oxidado e suplementada estes antioxidantes, Lin et al. (1989) encontraram no tecido muscular quantidades de BHT e BHA correspondentes a $8,8 \%$ do total de $\mathrm{BHT}$ e $0,8 \%$ do total de BHA adicionados às dietas. 
Inúmeros estudos e pesquisas foram conduzidos com a finalidade de avaliar a eficácia do uso de diversos antioxidantes nas rações animais. Tanto o BHT como o etoxiquim têm sido constantemente estudados e resultados positivos vêm confirmando a capacidade destes antioxidante sintéticos em proteger componentes de matérias-primas ou rações (Kirkland \& Fuller, 1971; March et al., 1962; Runnels et al., 1966 e Waldroup et al., 1960), aumentar a estabilidade da gordura, tecidos e órgãos animais (Asghar et al., 1989; Bailey et al., 1996; Bartov \& Bornstein, 1972 e 1981; Cabel et al., 1988; Kirkland \& Fuller, 1971; Lin et al., 1989 e Surak et al., 1977) e melhorar a performance dos animais submetidos a estresse oxidativo (Asghar et al., 1989; Bartov \& Bornstein, 1972; Cabel et al., 1988; Dibner et al., 1996; Lin et al., 1989; Robey \& Shermer, 1994 e Waldroup et al., 1960).

O trabalho que melhor avaliou o efeito do antioxidante e do peróxido na performance de frangos de corte foi desenvolvido por Cabel et al. (1988). Nesse estudo, a oxidação do óleo de visceras de aves foi induzida até os níveis de 0 , 50,100 e $175 \mathrm{meq} / \mathrm{kg}$ e posteriormente o óleo foi adicionado às dietas das aves de forma que estas resultassem em $0,2,4$ ou 7 meq de peróxidos $/ \mathrm{kg}$ de ração. $\mathrm{O}$ antioxidante etoxiquim foi adicionado às dietas aos niveis de $0,62,5$ e 125 $\mathrm{ppm}$. Os autores concluiram que os peróxidos podem afetar negativamente a performance dos frangos de corte e que a adição de etoxiquim pode aliviar estes efeitos. Aos 21 e 42 dias de idade, o peso vivo das aves que consumiram dietas com 4 ou 7 meq peróxido/kg de ração foi significativamente menor $(P<0,05)$. A conversão alimentar também foi afetada, no entanto, somente para os animais que consumiram dietas com os níveis mais elevados de peróxidos ( 7 $\mathrm{meq} / \mathrm{kg}$ ). A suplementação de 62,5 ou $125 \mathrm{ppm}$ de etoxiquim resultou em animais significativamente mais pesados aos 49 dias para os tratamentos com o mais alto nivel de peróxidos $(7 \mathrm{meq} / \mathrm{kg})$. Neste estudo, o nível mínimo de peróxidos necessário na dieta para provocar efeitos deletérios na performance dos animais foi o de $4 \mathrm{meq} / \mathrm{kg}$ de ração. A adição do etoxiquim apresentou pouco ou nenhum efeito quando as dietas continham niveis muito baixos de 
peróxidos, no entanto, a medida que o nivel de peróxidos aumentava, a suplementação de etoxiquim aliviou os seus efeitos negativos, especialmente na dosagem de $125 \mathrm{ppm}$. 


\section{MATERIAL E MÉTODOS}

\subsection{Local e Periodo Experimental}

O experimento foi conduzido nas instalações do Departamento de Produção Animal da Escola Superior de Agricultura "Luiz de Queiroz" da Universidade de São Paulo, localizada no município de Piracicaba, Estado de São Paulo.

O periodo experimental teve início no dia 31 de março e se estendeu até 10 de junho de 1.999, totalizando 71 dias. Este periodo correspondeu ao período de armazenamento da $\mathrm{FCO}$ e ao de criação das aves, que se restringiu aos últimos 42 dias (de 24 de abril até 10 de junho).

\subsection{Farinha de carne e ossos (FCO)}

Adquirimos um lote fresco de cerca de $400 \mathrm{~kg}$ de FCO do frigorifico Indústria Agroquímica Braido S/A, localizado em Itupeva/SP. Logo após a fase final de produção, a quantidade necessária para formar este lote foi ensacada e transportada diretamente para o galpão de armazenamento, localizado na fábrica de rações. No momento do ensaque foram retiradas amostras representativas do lote, que foram encaminhadas imediatamente para análise bromatológica e microbiológica. Os resultados analíticos referentes a composição e qualidade inicial da FCO podem ser observados na Tabela 3. 
Tabela 3. Composição inicial e indices de qualidade da FCO.

\begin{tabular}{|c|c|c|}
\hline ANÁLISES ${ }^{1}$ & UNIDADE & RESULTADO \\
\hline $\begin{array}{l}\text { Umidade Volátil } \\
\text { Teste de Rancidez } \\
\text { Indice de Peróxidos } \\
\text { Acidez } \\
\text { Proteína Bruta } \\
\text { Extrato Etéreo } \\
\text { Matéria Mineral } \\
\text { Cálcio } \\
\text { Fósforo }\end{array}$ & $\begin{array}{c}\% \\
\text { NEG/POS } \\
\text { meq/kg } \\
\text { meq/100g } \\
\% \\
\% \\
\% \\
\% \\
\%\end{array}$ & $\begin{array}{c}6,32 \\
\text { NEGATIVO } \\
0,00 \\
0,64 \\
41,12 \\
9,14 \\
41,11 \\
15,70 \\
7,53\end{array}$ \\
\hline $\begin{array}{l}\text { Áminoácidos } \\
\text { Ác. Aspártico } \\
\text { Treonina } \\
\text { Serina } \\
\text { Ác. Glutâmico } \\
\text { Prolina } \\
\text { Glicina } \\
\text { Alanina } \\
\text { Cistina } \\
\text { Valina } \\
\text { Metionina } \\
\text { Isoleucina } \\
\text { Leucina } \\
\text { Tirosina } \\
\text { Fenilalanina } \\
\text { Lisina } \\
\text { Histidina } \\
\text { Triptofano } \\
\text { Arginina }\end{array}$ & $\begin{array}{l}\% \\
\% \\
\% \\
\% \\
\% \\
\% \\
\% \\
\% \\
\% \\
\% \\
\% \\
\% \\
\% \\
\% \\
\% \\
\% \\
\% \\
\%\end{array}$ & $\begin{array}{l}3,12 \\
1,13 \\
1,56 \\
4,90 \\
4,36 \\
7,79 \\
3,67 \\
0,23 \\
1,44 \\
0,51 \\
0,95 \\
2,03 \\
0,63 \\
1,19 \\
2,07 \\
0,57 \\
0,07 \\
3,27\end{array}$ \\
\hline Salmonella & NEG/POS & NEGATIVO \\
\hline
\end{tabular}

${ }^{1}$ Análises realizadas pelo laboratório bromatológico da Multimix - Produtos e Serviços Agropecuários Ltda., localizado em Campinas/SP.

${ }^{2}$ Reação de Kreiss

3 Análise realizada pelo laboratório de análises microbiológicas Tech-Lab, em Campinas/SP. 
Uma terceira amostra, retirada juntamente com as demais, foi acondicionada em saco plástico impermeável e armazenada em freezer $\left(-20^{\circ} \mathrm{C}\right)$ para posteriormente ser submetida à uma extração com o uso de solvente (éter de petróleo) para que a fração de gordura fosse completamente retirada. A gordura extraída da FCO, cerca 30 gramas, foi acondicionada em um frasco de vidro hermeticamente fechado e armazenada em freezer $\left(-20^{\circ} \mathrm{C}\right)$ até ser encaminhada para análise. Este material foi analisado por cromatografia gasosa para identificação e quantificação dos principais ácidos graxos presentes (Tabela 4).

Tabela 4. Composição dos ácidos graxos da gordura extraída da FCO.

\begin{tabular}{|c|c|c|}
\hline ÁC.GRAXOS ${ }^{1}$ & $\begin{array}{c}\text { GORDURA }^{2} \\
(\%)\end{array}$ & $\begin{array}{c}\text { MAT. ORIGINAL }{ }^{3} \\
(\%)\end{array}$ \\
\hline mirístico $\left(\mathrm{C}_{14: 0}\right)$ & 2,95 & 0,27 \\
\hline palmítico $\left(C_{16: 0}\right)$ & 20,09 & 1,84 \\
\hline esteárico $\left(C_{18: 0}\right)$ & 18,93 & 1,73 \\
\hline oléico $\left(C_{18: 1}\right)$ & 26,12 & 2,39 \\
\hline linoléico $\left(C_{18: 2 \omega 6}\right)$ & 3,58 & 0,33 \\
\hline linolênico $\left(C_{18: 306}\right)$ & 1,14 & 0,10 \\
\hline Outros & 9,82 & 0,90 \\
\hline Total Saturados & 44,58 & 4,07 \\
\hline Total insaturados & 38,05 & 3,48 \\
\hline
\end{tabular}

1 Análises realizadas no laboratório da Unidade de Tecnologia do Pescado - FIPERJ, localizado no Rio de Janeiro/RJ

${ }^{2}$ Resultados obtidos na gordura extraída da FCO, expressos em \% da gordura

${ }^{3}$ Resultados expressos em porcentagem da matéria original, considerando-se $9,4 \%$ de EE da FCO 
Neste mesmo dia, o primeiro lote a ser preservado foi separado do lote original, pesado e homogeneizado juntamente com o antioxidante (BHT) na dosagem de 500 ppm num misturador em " $Y$ ", com capacidade para $30 \mathrm{~kg}$. $O$ restante do lote permaneceu ensacado e foi armazenado sobre tablados de madeira, em local coberto, seco, bem ventilado e fora do alcance da luz, reproduzindo as condições normais de armazenamento de uma fábrica de rações.

A cada 7 dias um lote foi sendo separado do lote original e tratado com o antioxidante, até que ao final das 4 semanas os 5 lotes de FCO estivessem preservados. Ressaltamos que a quantidade de BHT utilizada foi a mesma em todos os tratamentos (500 ppm), de acordo com a recomendação do fabricante.

Durante todo o período de armazenamento, as condições de temperatura e umidade relativa do ar no local foram monitoradas com o uso de um termohigrômetro da marca Amarell, modelo S 567938, através de uma leitura no final do dia, cujas médias estão apresentadas na Tabela 5. Os resultados das leituras diárias podem ser verificados no Apêndice 7 .

Tabela 5. Médias de máxima e mínima de temperatura e de umidade relativa do ar coletadas durante o periodo de armazenamento da FCO.

\begin{tabular}{lcccc}
\hline & \multicolumn{2}{c}{ TEMPERATURA $\left({ }^{\circ} \mathrm{C}\right)$} & \multicolumn{2}{c}{ UMIDADE RELATIVA $(\%)$} \\
\hline MÁXIMA & MÍNIMA & MÁXIMA & MÍNIMA \\
\hline Médias & 25 & 17 & 79 & 52 \\
\hline
\end{tabular}

Uma vez por semana, durante o periodo de armazenamento da FCO, foi coletada uma amostra de cada um dos lotes tratados e do lote não tratado e encaminhada imediatamente para o laboratório bromatológico da Multimix Produtos e Serviços Agropecuários Ltda., que fossem feitas as análises de umidade, teste de rancidez (Reação de Kreiss), índice de peróxidos e acidez. 


\subsection{Animais experimentais}

Foram utilizados 1.440 pintos de corte de um dia de idade, machos, da linhagem AgRoss, adquiridos do incubatório comercial Agroindústria Ninho Verde S/A, localizado na cidade de Tietê/SP.

\subsection{Instalações, Preparação e Condução do Experimento}

As dimensões do aviário experimental são 32 metros de comprimento por 8 metros de largura e 3 metros de pé-direito. O galpão tem orientação nordeste-sudoeste, é coberto com telhas de barro, com piso revestido de concreto, contém muretas laterais de alvenaria com 60 centímetros de altura, completamente telado e equipado com cortinas laterais. $\mathrm{O}$ aviário é dividido em 2 fileiras de 18 boxes cada uma, totalizando 36 boxes, sendo que as fileiras são separadas por um corredor de 2 metro de largura. Cada box possui área de 4,5 metros quadrados e uma porta de acesso ao corredor.

Antes da instalação do experimento o galpão passou por uma série de procedimentos de limpeza e desinfeção, que incluíram lavagem do piso e dos equipamentos, limpeza das cortinas, além do uso do lança-chamas no chão e nas telas. Em seguida, o material da "cama" de forração, uma mistura de maravalha de madeira e cascas de arroz foi espalhado, cobrindo o piso com uma camada de cerca de 10 centimetros de altura.

A iluminação do galpão foi feita por lâmpadas de 60 watts, localizadas na parte central do galpão.

Para o recebimento das aves cada box foi equipado com um bebedouro infantil contendo água fresca e um comedouro de $4 \mathrm{~kg}$ de capacidade, onde foram distribuídas as rações experimentais de acordo com os tratamentos previamente determinados.

Imediatamente após o recebimento das aves no galpão foi feita a sexagem para a certificação da presença somente de machos e a observação 
das condições gerais das aves. As fêmeas encontradas, bem como as aves em condições corporais ruins foram descartadas. As aves foram separadas em grupos de 40 , pesadas e distribuídas nos boxes de forma que o peso médio entre as unidades experimentais fosse o mais homogêneo possivel.

O aquecimento inicial das aves foi feito através do uso de lâmpadas infravermelhas de 250 watts, dispostas uma em cada box e suspensas a 0,5 metro do piso. As lâmpadas permaneceram acesas durante os primeiros 7 dias com a finalidade de manter a temperatura interna do galpão dentro de numa faixa ótima de temperatura (cerca de 32 a $33^{\circ} \mathrm{C}$ ) para o desenvolvimento inicial das aves. A manutenção da temperatura inicial foi auxiliada pela utilização de folhas de eucatex, na forma de círculo, que foram sendo ampliados gradualmente e completamente retirados do box na segunda semana.

Até o terceiro dia do experimento as aves mortas ou refugadas foram substituídas por aves sadias do mesmo lote e que estavam sendo criadas em outro galpão e recebendo dieta controle.

A partir do sétimo dia, os comedouros utilizados no início foram sendo substituídos pelos comedouros tubulares de capacidade de $25 \mathrm{~kg}$, que permaneceram até o final do experimento.

Diariamente era feita a limpeza dos bebedouros e a reposição da ração, além do registro da mortalidade (Apêndice 5).

Semanalmente todas as aves eram pesadas (Apêndice 1), assim como as sobras de ração para efetuarmos o controle do consumo (Apêndice 3). A substituição da ração inicial pela de crescimento ocorreu aos 21 dias e da ração de crescimento pela final, aos 35 dias. Essas mudanças foram feitas nos mesmos dias de pesagem.

A temperatura interna do galpão foi monitorada diariamente e medida na parte da manhã (Apêndice 6 ) com o uso de dois termômetros de máxima e mínima localizados um em cada fileira do galpão, um na parte anterior e outro na parte posterior, a cerca de 30 centimetros do piso. 
As aves foram vacinadas contra as doenças de Gumboro e Newcastle aos 12 dias de idade. As vacinas foram preparadas na diluição recomendada e administradas via água de beber, sendo que as aves permaneceram pelo menos 2 horas sem água. Após a distribuição das vacinas nos bebedouros foi feito um repasse para assegurar que todas as aves tivessem ingerido a quantidade necessária.

Periodicamente, as aves que se encontravam em mau estado, ou com peso menor que a metade do peso médio da parcela, eram retiradas do experimento, pesadas e consideradas refugos (Apêndice 5).

\subsection{Rações Experimentais}

O programa nutricional foi composto por 3 tipos de rações basais, destinadas às diferentes fases de criação das aves (inicial, crescimento e final). As rações foram fornecidas ad libitum durante todo o periodo experimental. A formulação das rações foi baseada no milho e no farelo de soja, sendo a farinha de carne e ossos (FCO) utilizada como única fonte de fósforo suplementar. As rações foram formuladas para conter $22 \%$ PB e $3.000 \mathrm{kcal} / \mathrm{kg}$ na fase inicial (do $1^{\circ}$ ao $21^{\circ}$ dia de idade), $21 \%$ PB e $3.050 \mathrm{kcal} / \mathrm{kg}$ na fase de crescimento (do $22^{\circ}$ ao $35^{\circ}$ dia de idade) e $19,5 \%$ PB e $3.100 \mathrm{kcal} / \mathrm{kg}$ na fase final (do $36^{\circ}$ ao $42^{\circ}$ dia de idade), sendo que as exigências de aminoácidos essenciais atenderam às relações aminoácido:lisina sugeridos por Rostagno et al. (1996).

A composição percentual das rações, bem como os níveis calculados estão apresentados na Tabela 6. 
Tabela 6. Composição percentual e níveis nutricionais calculados das rações.

\begin{tabular}{|c|c|c|c|}
\hline Ingrediente (\%) & Inicial & Crescimento & Final \\
\hline Milho & 59,88 & 62,37 & 66,25 \\
\hline Farelo de Soja & 33,04 & 30,35 & 26,90 \\
\hline $\mathrm{FCO}$ & 4,47 & 4,51 & 3,88 \\
\hline Óleo Vegetal & 1,36 & 1,66 & 1,74 \\
\hline Calcário & 0,45 & 0,33 & 0,49 \\
\hline Sal & 0,30 & 0,30 & 0,30 \\
\hline Supl. Vitam. e Min. & $0,30^{1}$ & $0,30^{2}$ & $0,30^{2}$ \\
\hline DL-Metionina 99 & 0,07 & 0,07 & 0,03 \\
\hline Cl. Colina $60^{3}$ & 0,03 & 0,02 & 0,01 \\
\hline Supl. Aditivos & $0,10^{4}$ & $0,10^{5}$ & $0,10^{5}$ \\
\hline \multirow[t]{2}{*}{ TOTAL } & 100,0 & 100,0 & 100,0 \\
\hline & \multicolumn{3}{|c|}{ Niveis Calculados } \\
\hline EM kcal/kg & 3.000 & 3.050 & 3.100 \\
\hline PB \% & 22,00 & 21,00 & 19,50 \\
\hline Extrato Etéreo \% & 4,00 & 4,35 & 4,48 \\
\hline Metionina \% & 0,53 & 0,51 & 0,45 \\
\hline Met + Cis $\%$ & 0,88 & 0,85 & 0,77 \\
\hline Lisina \% & 1,16 & 1,09 & 0,99 \\
\hline Cálcio \% & 1,00 & 0,95 & 0,90 \\
\hline Fósforo Disponível \% & 0,45 & 0,45 & 0,40 \\
\hline
\end{tabular}

1-Concentração por $\mathrm{kg}$ de produto: vit. A 2.250 .000 Ul; vit. $D_{3} 450.000$ Ul; vit. $E 5,25$ g; vit. $K$ $0,36 \mathrm{~g}$; vit. $B_{2} 1,13 \mathrm{~g}$; vit. $B_{12} 3,75 \mathrm{mg}$; pantotenato de Ca $2,58 \mathrm{~g}$; metionina $325 \mathrm{~g}$; niacina 7,46 g; colina $62,25 \mathrm{~g}$; selênio $52 \mathrm{mg}$; antioxidante $1,25 \mathrm{~g}$; manganês $14,5 \mathrm{~g}$; cobre $12,5 \mathrm{~g}$; zinco 12,5 $\mathrm{g}$; ferro $14 \mathrm{~g}$; iodo $0,15 \mathrm{~g}$; cobalto $21 \mathrm{mg}$.

2-Concentração por $\mathrm{kg}$ de produto: vit. A 1.875 .000 Ul; vit. $D_{3} 375.000$ Ul; vit. $E 3,25 \mathrm{~g}$; vit. $\mathrm{K}$ $0,27 \mathrm{~g}$; vit. $B_{2} 0,90 \mathrm{~g}$; vit. $B_{12} 2,5 \mathrm{mg}$; pantotenato de Ca $1,99 \mathrm{~g}$; metionina $300 \mathrm{~g}$; niacina $6,27 \mathrm{~g}$; colina $48,8 \mathrm{~g}$; selênio $43 \mathrm{mg}$; antioxidante $1,28 \mathrm{~g}$; manganês $14,5 \mathrm{~g}$; cobre $1,75 \mathrm{~g}$; zinco $12,5 \mathrm{~g}$; ferro $14 \mathrm{~g}$; iodo $0,15 \mathrm{~g}$; cobalto $21 \mathrm{mg}$.

3- $52 \%$ de colina.

4- Nicarbazina $50 \mathrm{mg} / \mathrm{kg}$; avilamicina $6 \mathrm{mg} / \mathrm{kg}$; olaquindox $50 \mathrm{mg} / \mathrm{kg}$.

5 - Avilamicina $5 \mathrm{mg} / \mathrm{kg}$; olaquindox $40 \mathrm{mg} / \mathrm{kg}$; ácido 3-nitro $30 \mathrm{mg} / \mathrm{kg}$; monensina sódica 110 $\mathrm{mg} / \mathrm{kg}$. 


\subsection{Tratamentos e Delineamento Experimental}

Os tratamentos experimentais foram:

- CONTROLE: dieta contendo FCO sem adição de antioxidante durante todo o período de armazenamento;

- BHT/O : dieta contendo FCO com adição do antioxidante BHT no dia zero;

- BHT/7 : dieta contendo FCO com adição do antioxidante BHT aos 7 dias de armazenamento;

- BHT/14 : dieta contendo FCO com adição do antioxidante BHT aos 14 dias de armazenamento;

- BHT/21 : dieta contendo FCO com adição do antioxidante BHT aos 21 dias de armazenamento;

- BHT/28 : dieta contendo FCO com adição do antioxidante BHT aos 28 dias de armazenamento.

O delineamento experimental adotado foi em blocos casualizados, com 6 tratamentos e 6 repetições e 40 aves por unidade experimental.

\subsection{Variáveis Estudadas:}

As variáveis estudadas foram o peso vivo das aves (PV), ganho de peso $(G P)$, consumo de ração (CR), conversão alimentar (CA), mortalidade + refugagem (MR) e fator de produção (FP). Todos os valores representam a média de cada parcela.

Os valores de peso vivo foram obtidos pela divisão do peso total da parcela pelo número de aves vivas no momento da pesagem. O ganho de peso foi calculado por diferença entre o peso vivo médio do momento e o peso vivo 
médio da semana anterior. O consumo de ração foi determinado dividindo-se a quantidade de ração consumida na semana (ração fornecida menos sobra) pelo número de aves vivas. Nos casos em que havia mortalidade de aves 0 consumo de ração do box foi corrigido levando-se em conta uma estimativa do alimento perdido consumido pela ave que morreu, através da seguinte fórmula:

$\mathrm{CA}$ ajustada $=($ consumo de ração da semana $) /\{($ peso das aves vivas $)+$ ( peso das aves mortas) $\}$ - (peso das aves vivas da semana anterior)

$\mathrm{CR}$ corrigido $=\mathrm{CA}$ ajustada $\times$ ganho de peso

A conversão alimentar foi calculada através da divisão do consumo de ração pelo ganho de peso das aves do box no periodo.

A mortalidade e o peso das aves mortas foram registrados no dia da ocorrência e está expressa em porcentagem juntamente com a refugagem.

O fator de produção foi calculado ao final dos 42 dias do experimento, da seguinte maneira:

$\mathrm{FP}=$ ganho de peso médio $(\mathrm{g}) \times$ viabilidade $(\%) / \mathrm{CA} \times 10$

\subsection{Análise Estatística:}

Os dados obtidos no ensaio de desempenho para as variáveis dependentes ( $P V, G P, C R, C A, M R$ e FP) foram agrupados em três periodos: 1 a 21 dias, 22 a 42 dias e 1 a 42 dias. Foram então submetidos à análise de variância utilizando-se os procedimentos General Linear Models (GLM) do pacote computacional Statistical Analyses System (SAS Institute, 1989).

O esquema da análise da variância está apresentado na Tabela 7. 
Tabela 7. Esquema da análise da variância.

\begin{tabular}{cc}
\hline Causas de Variação & Graus de liberdade \\
\hline Tratamentos & 5 \\
Blocos & 5 \\
Resíduo & 25 \\
\hline Total & 35 \\
\hline
\end{tabular}

As médias calculadas para cada tratamento foram comparadas com o tratamento CONTROLE através do teste de Dunnett ao nivel de significância de 0,05 .

O modelo matemático associado ao delineamento utilizado foi:

$$
Y_{i j}=\mu+t_{i}+b_{j}+e_{i j} ;
$$

$i=1,2,3,4,5,6 \quad$ e $\quad j=1,2,3,4,5,6$

onde:

$Y_{i j}=$ resposta observada do i-ésimo tratamento no j-ésimo bloco;

$\mu=$ média geral;

$t_{i}=$ efeito do i-ésimo tratamento;

$b_{j}=$ efeito do j-ésimo bloco;

$e_{i j}=$ erro aleatório 


\section{RESULTADOS E DISCUSSÃO}

\subsection{Composição e qualidade inicial da FCO}

As análises efetuadas na amostra inicial, que descrevem a composição e qualidade da FCO (análise bromatológica, microbiológica e o perfil de ácidos graxos) utilizada neste experimento, foi descrita no item 3.2 .

\subsection{Qualidade da FCO armazenada}

No decorrer dos 70 dias de armazenamento da FCO, foi coletada uma amostra por semana de cada lote de FCO, tratado ou não. Logo após a coleta, estas amostras eram conduzidas para o laboratório bromatológico, para a realização imediata das análises de umidade volátil, indice de peróxidos (IP), acidez e teste de rancidez. Deve-se ressaltar que houve esta preocupação com a rápida análise as amostras de FCO para que o seu estado de conservação fosse avaliado naquele exato momento, uma vez que o IP pode se modificar com o avançar do tempo e com a maior exposição ao oxigênio atmosférico. Este procedimento foi adotado com a finalidade de avaliar periodicamente $\mathrm{e}$ acompanhar o estado de conservação da FCO submetida aos diferentes tratamentos.

O Índice de Peróxidos (IP, em meq/kg de gordura) foi usado como principal parâmetro de avaliação da qualidade por este ser um bom método para medir a oxidação nas gorduras (Kirkland \& Fuller, 1970; Shermer \& 
Calabotta, 1985). O IP inicial da FCO utilizada foi zero e, como podemos observar (Tabelas 8 a 13 e Figura 3), permaneceu em zero até a primeira semana, em todos os tratamentos.

$\mathrm{Na}$ Tabela 8 observamos os resultados das análises de umidade, teste de rancidez, índice de peróxidos e acidez das amostras do lote de FCO sem adição do BHT durante todo o armazenamento (tratamento CONTROLE). Através da observação dos resultados do IP (Figura 3) podemos verificar 0 comprometimento da qualidade desta farinha no decorrer do tempo.

Neste tratamento, a partir da segunda semana (13/04), houve uma rápida elevação no IP $(34,29 \mathrm{meq} / \mathrm{kg})$, ultrapassando $10 \mathrm{meq} / \mathrm{kg}$, limite máximo estabelecido pelo Compêndio (1998) para as farinhas de carne. O IP foi se elevando gradualmente até atingir o seu valor mais alto $(79,72 \mathrm{meq} / \mathrm{kg})$ na $8^{\mathrm{a}}$ semana (25/5). Esta elevação do IP é acompanhada pelo teste de rancidez positivo (ou reação de Kreiss), que confirma a ocorrência da oxidação e a presença de compostos secundários destas reações. Nesta fase, uma série de alterações ocorrem no material, além da formação dos peróxidos, transformações estas que incluem modificações nas características organolépticas do material com pronunciadas mudanças no odor e no sabor do material oxidado. Além disso, ocorrem também alterações na composição dos ácidos graxos da gordura, além do comprometimento das vitaminas lipossolúveis e da fração energética do alimento.

Apesar destes parâmetros não terem sido avaliados, a presença de peróxidos e outros compostos nos alimentos oxidados e os seus efeitos prejudiciais aos ácidos graxos e demais componentes dos alimentos são amplamente conhecidos (Engberg et al., 1996; Kirkland \& Fuller, 1971; Shermer \& Calabotta, 1985). 


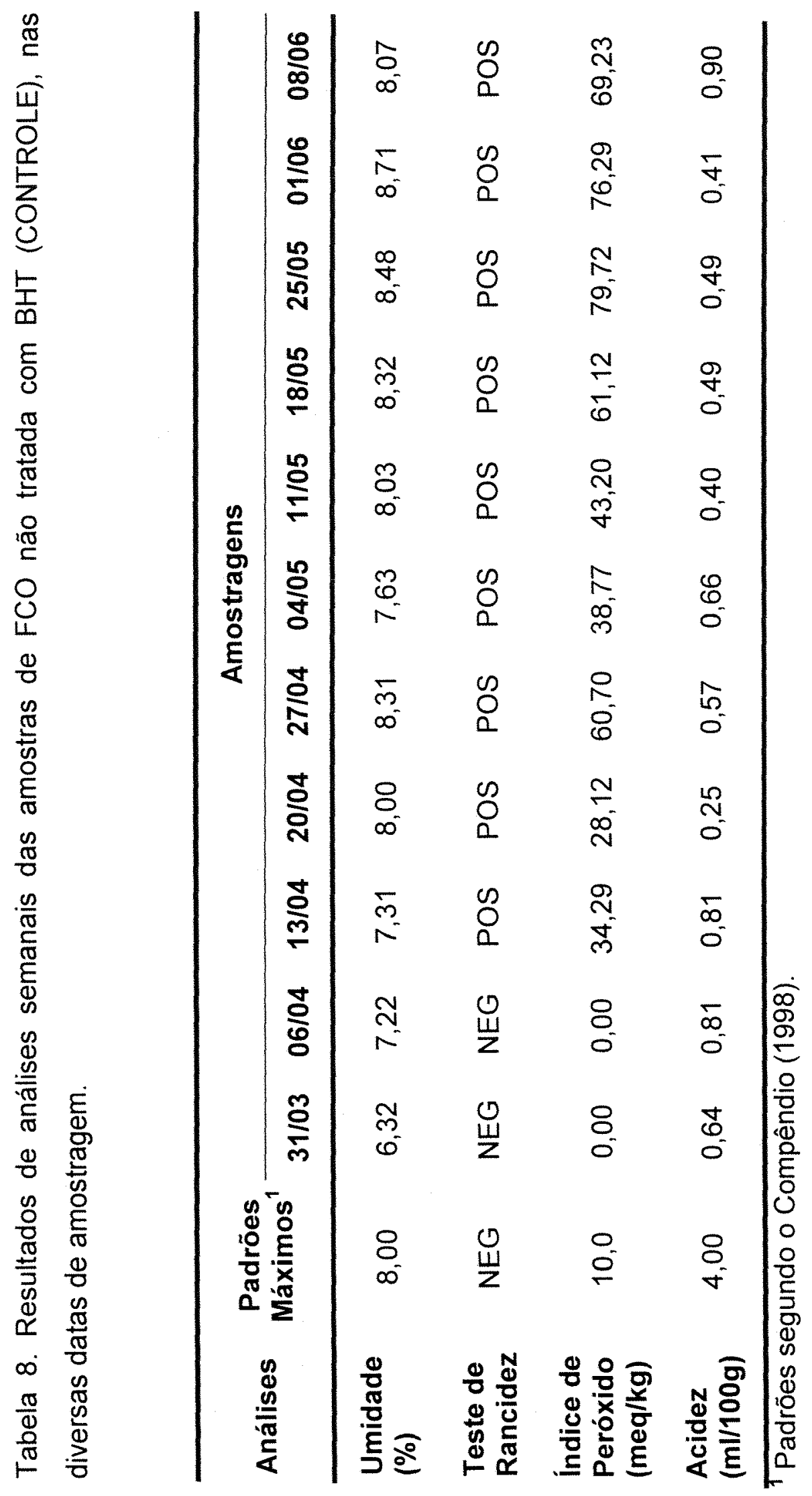




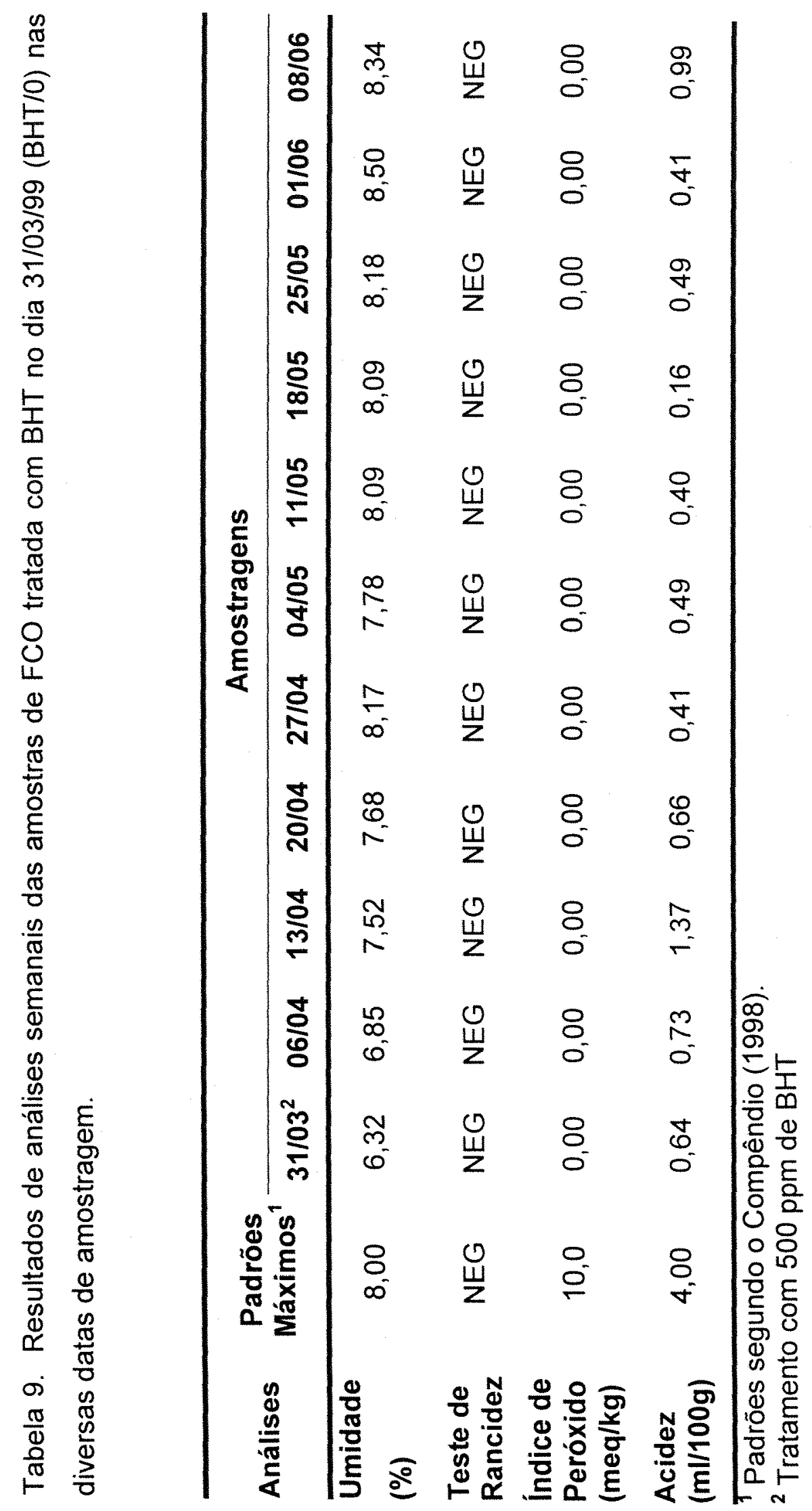




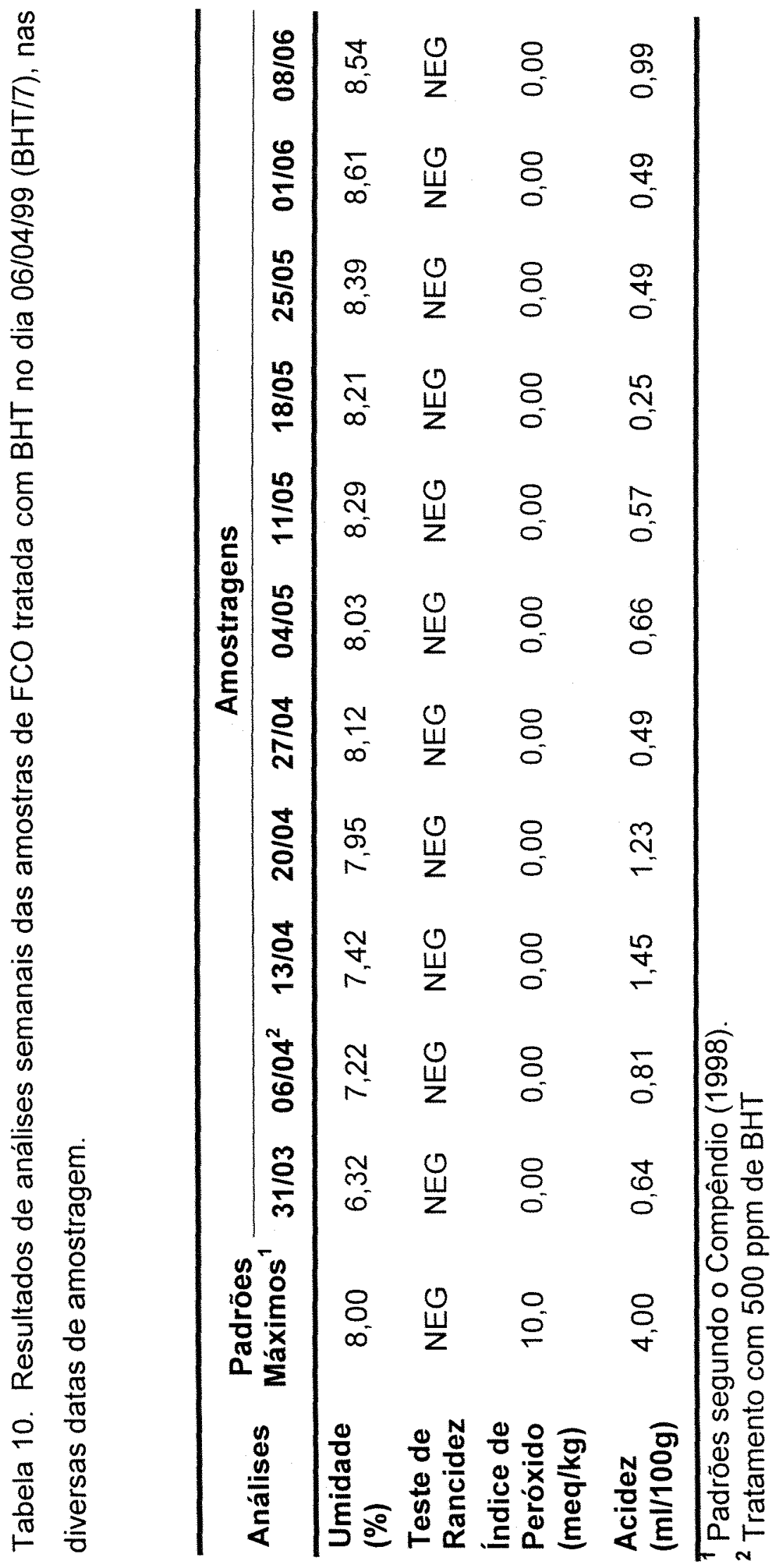




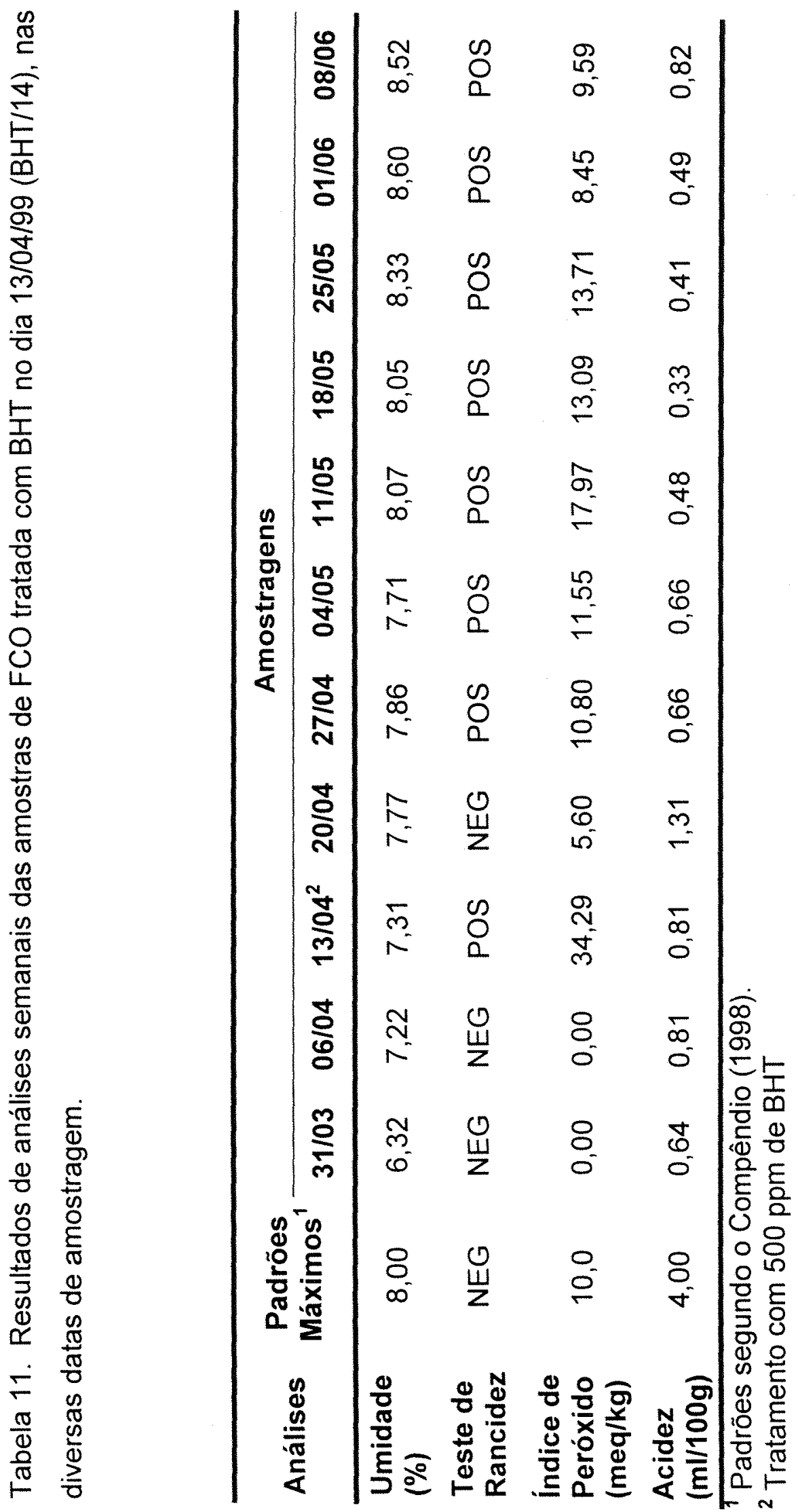




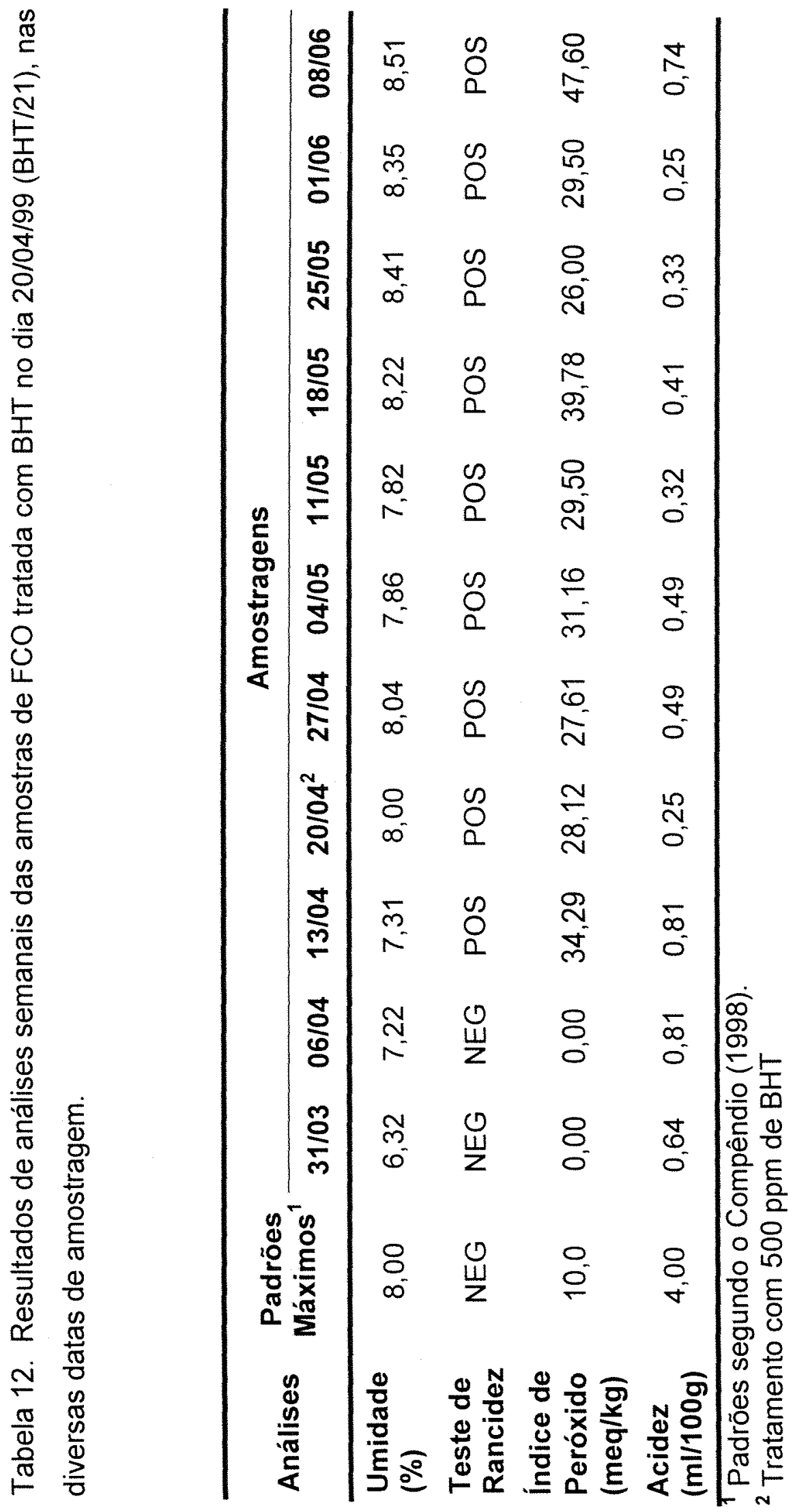




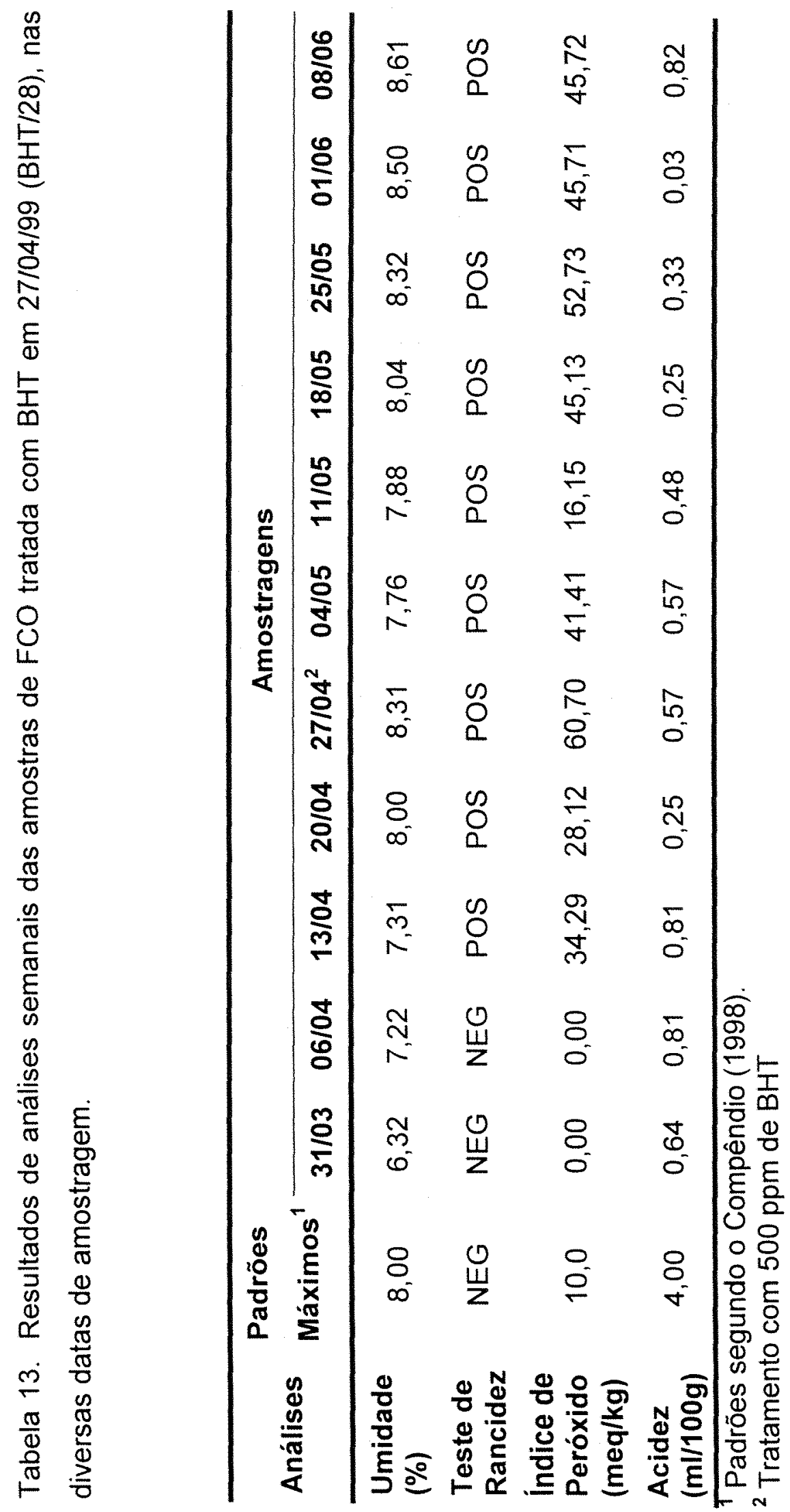




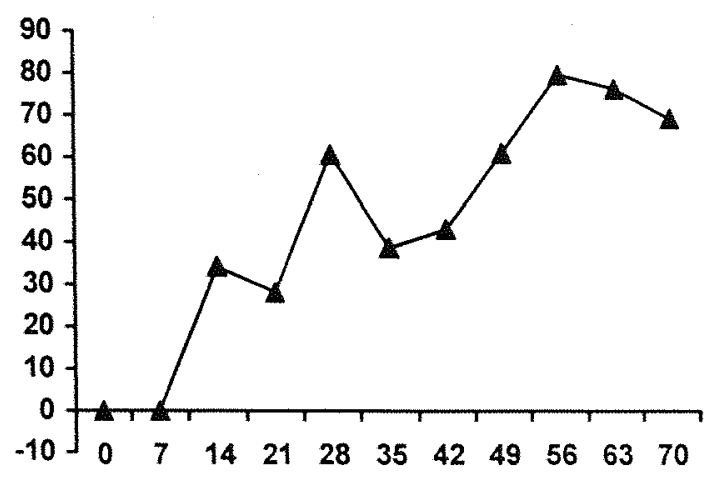

(a)

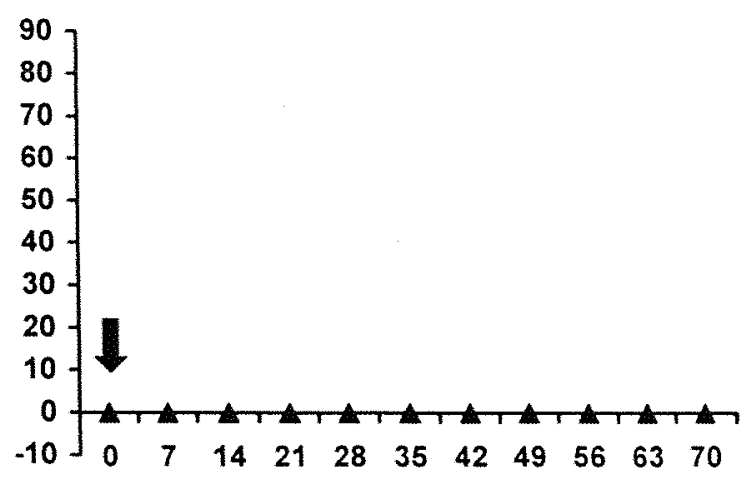

(b)

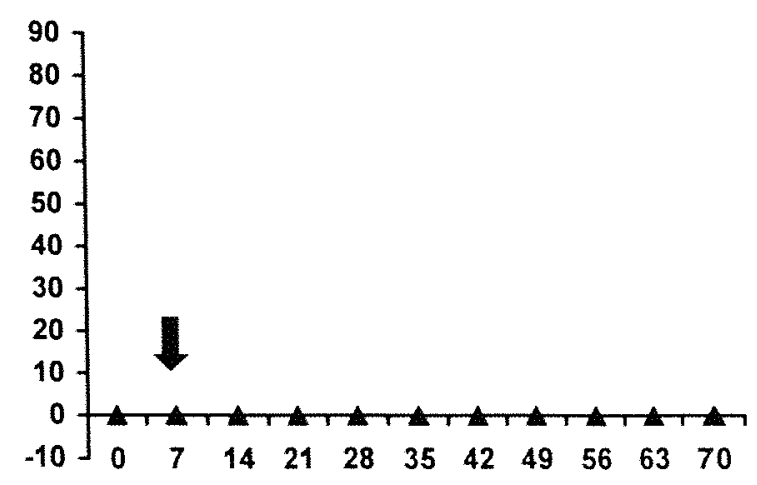

(c)

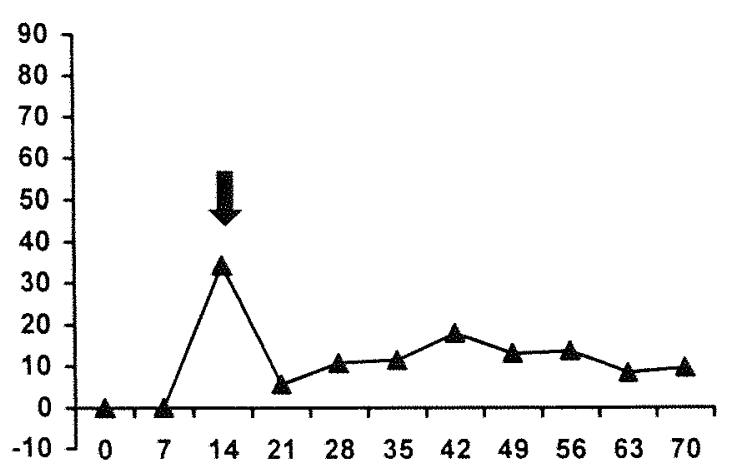

(d)

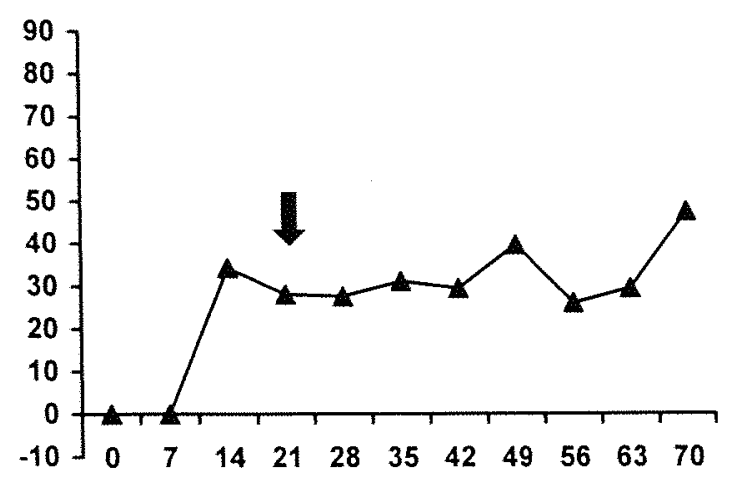

(e)

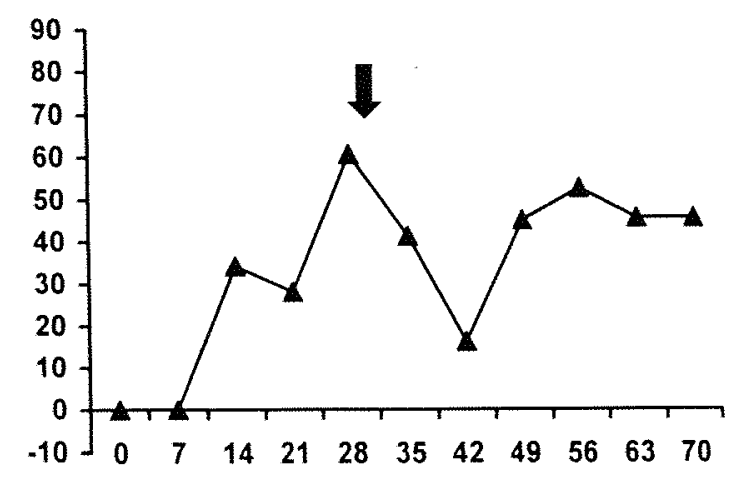

(f)

Figura 3. Índice de peróxidos (IP, meq $/ \mathrm{kg}$ ) das amostras de $\mathrm{FCO}$ analisadas semanalmente para os tratamentos: (a) CONTROLE, (b) BHT/O, (c) BHT/7, (d) $\mathrm{BHT} / 14$, (e) BHT/21 e (f) BHT/28. As setas indicam as adiçōes do BHT. 
Quando comparamos os dados do tratamento CONTROLE com os tratamentos $\mathrm{BHT} / 0$ ou $\mathrm{BHT} / 7$ (Tabelas 9 e 10, e Figura 3), podemos verificar com clareza o efeito da adição do antioxidante na preservação das gorduras. Este efeito positivo do uso do antioxidante no controle do processo oxidativo tem sido comprovado por diversos autores (Asghar et al., 1989; Bartov \& Bornstein, 1972; Cabel et al., 1988; Kirkland \& Fuller, 1971; Lin et al., 1989 e March et al., 1960). Quando o antioxidante foi adicionado logo no início do armazenamento (BHT/0) ou após 7 dias (BHT/7), não houve nenhum registro de formação de peróxidos durante todo o periodo analisado, uma vez que o IP manteve-se sempre zero. Aliado a isso, o teste de rancidez negativo confirmou a ausência de oxidação das gorduras.

Ao observarmos os resultados obtidos para o tratamento BHT/14 (Tabela 11) na qualidade da FCO, verificamos o que ocorreu quando adicionamos $O$ antioxidante após 14 dias de armazenamento, quando o IP já havia se elevado para $34,29 \mathrm{meq} / \mathrm{kg}$. Nota-se o efeito do antioxidante nas análises da semana seguinte (20/04), onde, apesar do processo oxidativo já iniciado, O IP foi reduzido para $5,60 \mathrm{meq} / \mathrm{kg}$, voltando a subir e mantendo-se próximo ao limite de $10 \mathrm{meq} / \mathrm{kg}$ estabelecido pelo Compêndio (1998) nas duas últimas amostragens. Quando observamos os resultados do IP do tratamento CONTROLE neste mesmo periodo, verificamos que o IP continuou se elevando quando a FCO não foi tratada com o antioxidante.

Ressaltamos que, apesar da alta eficácia do antioxidante no controle da rancidez, este não é capaz de eliminar ou reduzir os efeitos tóxicos causados pelos metabólitos secundários resultantes da oxidação (Wang et al., 1997).

$O$ efeito positivo da adição do BHT continuou sendo observado nos tratamentos BHT/21 (Tabela 12) e BHT/28 (Tabela 13), no entanto, em menor intensidade. Os IP verificados nestes tratamentos não chegaram a alcançar os niveis observados no tratamento CONTROLE, mas os valores ainda foram altos. Na última amostragem, realizada no dia 08/06 o IP do tratamento BHT/21 chegou a $47,60 \mathrm{meq} / \mathrm{kg}$. Quando a adição de antioxidante foi feita na FCO com 
IP elevado $(60,70 \mathrm{meq} / \mathrm{kg}$ no tratamento $\mathrm{BHT} / 28)$, os resultados do IP nas amostragens seguintes foram menores que o CONTROLE (sem antioxidante), mas ainda foram altos. Nestes casos, a adição do antioxidante não provocou o efeito desejado sobre o IP.

$\mathrm{Em}$ todos os tratamentos verificamos que o teor de umidade da FCO elevou-se ligeiramente durante as 10 semanas de armazenamento, talvez devido à alta umidade relativa do ar verificada neste período (Apêndice 7) e característica da época do ano em que o experimento foi realizado, o que pode ter contribuído um pouco na aceleração do processo oxidativo.

Os resultados de análise da acidez nas amostras manteve-se dentro dos limites aceitáveis $(<4 \mathrm{ml} / 100 \mathrm{~g})$ em todos os tratamentos. Estes resultados estão de acordo com os padrões estabelecidos oficialmente pelo Compêndio (1998) e indicam que não houve o desenvolvimento de outro tipo de rancidez neste produto capaz de provocar a produção de ácidos graxos livres, como no caso da rancidez hidrolítica.

As farinhas armazenadas foram adicionadas às rações em cerca de $4 \%$, conforme a composição das rações apresentada anteriormente (Tabela 6) e fornecidas às aves para avaliação do desempenho, cujos resultados serão apresentados e discutidos a seguir.

\subsection{Resultados de desempenho}

De uma maneira geral, neste experimento obtivemos excelentes resultados de desempenho das aves. O ganho de peso diário (GPD) médio foi de 61,0 gramas/ave, o consumo de ração (CR) médio foi de $4,5 \mathrm{~kg}$ e o peso vivo (PV) médio foi de $2,60 \mathrm{~kg}$ aos 42 dias. Estes resultados estão acima da curva padrão da linhagem, o que indica que as condições de ambiente, nutricionais e de sanidade foram adequadas ao desenvolvimento dos animais e contribuiram muito para o bom desempenho. Da mesma maneira, os resultados obtidos para a conversão alimentar (CA) apresentaram-se em torno de 1,75 e a 
mortalidade (MR), apesar não apresentar diferenças significativas entre os tratamentos, variou de 0,4 a $7,9 \%$. No entanto, como o elevado ganho de peso esteve associado a MR baixas, isso produziu valores semelhantes para o fator de produção (FP) nos diferentes tratamentos, que estiveram em torno de 332 .

Outro aspecto a ser destacado é que os coeficientes de variação (CV) obtidos para as principais variáveis foram bastante baixos, indicando que os erros experimentais foram pequenos, evidenciando os cuidados na condução do experimento.

Apresentamos nas tabelas a seguir os resultados médios de desempenho das aves divididos entre os periodos de 1 a 21 dias, de 21 a 42 dias e no período total de criação, de 1 a 42 dias de criação. Os dados coletados durante o período experimental, por parcela, estão apresentados nos Apêndices 1 a 5 .

No período inicial de criação, ou seja, de 1 a 21 dias de idade (Tabela 14), o ganho de peso (GP) foi semelhante somente para as aves que consumiram a ração CONTROLE e para as aves do tratamento BHT/7. Os demais tratamentos, onde a FCO foi tratada com antioxidante nos dias $0,14,21$ e 28, tratamentos $\mathrm{BHT} / 0, \mathrm{BHT} / 14, \mathrm{BHT} / 21$ e $\mathrm{BHT} / 28$, respectivamente, foram significativamente inferiores $(P<0,05)$ ao CONTROLE, onde a FCO não foi tratada com BHT. Neste caso, não houve efeito benéfico da adição do BHT à FCO, mesmo quando feita logo no início do armazenamento.

$O$ consumo de ração $(C R)$ no período não foi afetado pela adição do antioxidante, exceto para a inclusão do BHT aos 28 dias de armazenamento (BHT/28), cujo valor foi significativamente $(P<0,05)$ inferior ao CONTROLE. Não houve efeito de nenhum dos tratamentos $(P>0,05)$ sobre a $C A$ e MR, quando comparados com o CONTROLE. 
Tabela 14. Resultados médios do ganho de peso (GP), consumo de ração $(C R)$, conversão alimentar (CA), mortalidade + refugagem (MR) por tratamento no periodo de 1 aos 21 dias de idade.

\begin{tabular}{|c|c|c|c|}
\hline \multirow{2}{*}{ Tratamento } & \multicolumn{3}{|c|}{ Variáveis } \\
\hline & CR (kg) & CA (\%) & MR (\%) \\
\hline CONTROLE & 1,166 & 1,423 & 2,9 \\
\hline BHT/O & $0,796 *$ & 1,457 & 0,4 \\
\hline BHT $/ 7$ & 1,176 & 1,440 & 3,8 \\
\hline BHT/14 & $0,799 *$ & 1,435 & 1,3 \\
\hline BHT/21 & $0,790 *$ & 1,475 & 1,3 \\
\hline $\mathrm{BHT} / 28$ & $0,783 *$ & 1,426 & 1,3 \\
\hline$C V^{1}(\%)$ & 2,50 & 2,80 & 93,68 \\
\hline \multicolumn{4}{|c|}{ * Médias diferem do CONTROLE pelo teste de Dunnett $(P<0.05)$} \\
\hline $\begin{array}{l}\text { Nesta fase } \\
\text { estatisticamente si } \\
\text { tratamentos estuc } \\
\text { Bornstein (1972) } \\
\text { conversão em fun } \\
\text { não com antioxida } \\
\text { CA até os } 14 \text { dias } \\
\text { frangos de corte a } \\
\text { resultados obtido } \\
\text { (1997), que des } \\
\text { significativas (P< } \\
\text { sendo que o de } \\
\text { prejudicado. }\end{array}$ & $\begin{array}{l}\text { al de criação não ver } \\
\text { tivas para a conversão a } \\
\text { Estes resultados estã } \\
\text { não verificaram efeitos } \\
\text { adição de óleo oxidado } \\
\text { Dibner et al. (1996) não } \\
\text { berg et al. (1996) não ve } \\
\text { ados com dieta contend } \\
\text { e estudo discordam dos } \\
\text { fase inicial (1 a } 21 \\
\text { no ganho de peso, con } \\
\text { nho das aves alimenta }\end{array}$ & $\begin{array}{l}\text { mos tam } \\
\text { ntar (CA) } \\
\text { e acordo } \\
\text { etérios } n \\
\text { dieta de fr } \\
\text { ntraram } \\
\text { aram alter } \\
\text { to oxidad } \\
\text { tidos por } \\
\text { to encontr } \\
\text { com gor }\end{array}$ & $\begin{array}{l}\text { diferenças } \\
\text { henhum dos } \\
\text { Bartov \& } \\
\text { nho ou na } \\
\text { s tratada ou } \\
\text { nças para a } \\
\text { s na CA em } \\
\text { entanto, os } \\
\text { g, S. et al. } \\
\text { diferenças } \\
\text { o alimentar, } \\
\text { oxidada foi }\end{array}$ \\
\hline
\end{tabular}


A maioria dos estudos que envolvem a avaliação dos efeitos do estresse oxidativo em aves geralmente abrange o periodo final de criação; resultando numa escassez de resultados para comparação nesta fase inicial.

$\mathrm{Na}$ fase final de criação das aves, que corresponde ao periodo de 21 até 42 dias de idade (Tabela 15), a utilização do antioxidante BHT não influenciou as variáveis GP, CR ou MR quando comparadas com o tratamento CONTROLE $(P>0,05)$, que não sofreu tratamento com o antioxidante. Somente a $C A$ calculada neste periodo para o tratamento BHT/14, em que a adição de BHT foi feita aos 14 dias de armazenamento, foi melhorada em $1,5 \%(P<0,05) \mathrm{em}$ relação ao tratamento CONTROLE. Contudo, este é um resultado isolado e discordante dos resultados dos demais tratamentos em que o BHT foi adicionado, no início ou no final do armazenamento. Além disso, os resultados do IP para a FCO submetida a este tratamento também não justificam este comportamento.

Tabela 15. Resultados médios do ganho de peso (GP), consumo de ração $(C R)$, conversão alimentar (CA), mortalidade + refugagem (MR) por tratamento no período de 21 aos 42 dias de idade.

\begin{tabular}{lcccc}
\hline \multirow{2}{*}{ Tratamento } & \multicolumn{4}{c}{ Variáveis } \\
\cline { 2 - 5 } & GP (kg) & CR (kg) & CA (\%) & MR (\%) \\
\hline CONTROLE & 1,750 & 3,351 & 1,915 & 2,1 \\
BHT/0 & 1,751 & 3,334 & 1,903 & 2,5 \\
BHT/7 & 1,805 & 3,422 & 1,896 & 4,2 \\
BHT/14 & 1,770 & 3,337 & $1,885 *$ & 2,5 \\
BHT/21 & 1,788 & 3,399 & 1,901 & 3,3 \\
BHT/28 & 1,714 & 3,258 & 1,902 & 1,7 \\
\hline CV $1 \%)$ & 2,10 & 0,82 & 2,10 & 78,37 \\
\hline
\end{tabular}

${ }^{1}$ Coeficiente de Variação

* Médias diferem do CONTROLE pelo teste de Dunnett $(P<0.05)$. 
Neste periodo, destacamos também o ganho de peso e o consumo das aves submetidas ao tratamento com BHT aos 7 dias, que foram numericamente superiores ao CONTROLE. Apesar destas diferenças não serem estatisticamente significativas $(P>0,05)$, o ganho de peso foi $55,0 \mathrm{~g}$ superior, sendo acompanhado pelo consumo que foi $71,0 \mathrm{~g}$ maior para o tratamento $\mathrm{BHT} / 7$. O GP e CR das aves do tratamento BHT/28 acompanharam a tendência verificada no período inicial ( 1 a 21 dias), com reduções de $2,0 \%$ e 2,8\% em relação ao CONTROLE, respectivamente. Contudo, neste período (de 21 a 42 dias), as diferenças verificadas para estas variáveis não foram estatisticamente significativas $(P>0,05)$.

Quando analisamos os resultados de desempenho obtidos para o periodo total de criação das aves (de 1 a 42 dias) podemos verificar mais claramente os resultados deste estudo (Tabela 16). Os valores obtidos para as variáveis $P V, G P D$ e $C R$, foram significativamente inferiores $(P<0,05)$ para 0 tratamento $\mathrm{BHT} / 28$, quando comparados ao tratamento CONTROLE. Porém, se observarmos os resultados deste mesmo tratamento (BHT/28) para o período de 1 a 21 dias, constatamos que o GP e CR já se apresentavam menores em comparação com o CONTROLE $(P<0,05)$ e mantiveram esta tendência também na fase final (21 a 42 dias) do experimento. A redução do ganho de peso foi devida exclusivamente à depressão no consumo de ração, uma vez que a CA não foi afetada $(P>0,05)$. Ainda em relação a essas variáveis, os demais tratamentos (BHT/0, BHT/7, BHT/14 ou BHT/21) não apresentaram resultados estatisticamente diferentes $(P>0,05)$ do CONTROLE. 
Tabela 16. Resultados médios de peso vivo aos 42 dias (PV), consumo de ração (CR), conversão alimentar (CA), ganho de peso diário (GPD), mortalidade + refugagem (MR) e fator de produção (FP) por tratamento no período de 1 a 42 dias de idade.

\begin{tabular}{lcccccc}
\hline \multirow{2}{*}{ Tratamento } & \multicolumn{6}{c}{ Variáveis } \\
\cline { 2 - 7 } & PV(kg) & CR (kg) & CA (\%) & GPD (kg) & MR (\%) & FP \\
\hline CONTROLE & 2,609 & 4,517 & 1,758 & 0,061 & 5,0 & 330,7 \\
BHT/0 & 2,587 & 4,493 & 1,764 & 0,061 & 2,9 & 333,5 \\
BHT/7 & 2,662 & 4,598 & 1,754 & 0,062 & 7,9 & 327,8 \\
BHT/14 & 2,609 & 4,483 & 1,745 & 0,061 & 3,8 & 337,3 \\
BHT/21 & 2,618 & 4,565 & 1,770 & 0,061 & 4,6 & 332,6 \\
BHT/28 & $2,536 *$ & $4,375 *$ & 1,753 & $0,059 *$ & 2,9 & 329,4 \\
\hline CV $1 \%)$ & 1,54 & 1,75 & 0,97 & 1,57 & 56,87 & 3,88 \\
\hline
\end{tabular}

${ }^{1}$ Coeficiente de Variação

* Médias diferem do CONTROLE pelo teste de Dunnett $(P<0.05)$.

As aves alimentadas com ração contendo FCO tratada com BHT não apresentaram diferenças significativas $(P>0,05)$ quando comparados com 0 CONTROLE para as variáveis CA, MR ou FP. Para estas variáveis, a utilização do antioxidante não representou nenhuma vantagem.

Embora tenha sido verificada diferença significativa $(P<0,05)$ do tratamento $\mathrm{BHT} / 28$ em relação ao CONTROLE, de maneira geral, não há indicativos de que o uso do antioxidante BHT na FCO utilizada neste estudo influenciou o desempenho das aves, uma vez que não observamos diferenças nas variáveis estudadas para os animais que consumiram as rações produzidas com a FCO tratada comparativamente com a não tratada (CONTROLE).

Os resultados obtidos neste estudo estão em concordância com alguns autores (Kirkland \& Fuller, 1971; Runnels et al., 1966; Waldroup et al., 1981), que não obtiveram resultados positivos no desempenho das aves com o uso de 
antioxidantes nas rações. No entanto, discordam de outros estudos como de Lin et al.(1989) que verificaram um aumento significativo no peso da carcaça e na eficiência de utilização da dieta pelas aves quando uma mistura de antioxidantes $(\mathrm{BHA}+\mathrm{BHT})$ foi utilizada nas rações, em relação ao controle sem antioxidantes.

Engberg et al. (1996) avaliaram a retenção de energia e de gordura pelos frangos alimentados com óleo fresco ou oxidado adicionado às dietas. Estes autores encontraram reduções significativas $(P=0,07)$ nos valores de retenção de energia e de gordura em função da pior qualidade do óleo ingerido.

Com o acompanhamento da qualidade da FCO feito através das análises periódicas das amostras coletadas dos lotes armazenados, constatamos claramente a ocorrência da rancidez oxidativa durante o armazenamento. A FCO não tratada com antioxidante atingiu praticamente $80 \mathrm{meq}$ de peróxidos $/ \mathrm{kg}$. Apesar disso, quando incluímos a FCO nas rações, ao nível de aproximadamente $4 \%$, este valor foi diluído, reduzindo o IP da ração para 0,3 $\mathrm{meq} / \mathrm{kg}$.

Cabel et al. (1988) utilizaram níveis de peróxidos que variaram de 0 a 7 meq/ $\mathrm{kg}$ de ração. Estes autores constataram pouco ou nenhum efeito da adição de etoxiquim sobre o peso vivo e sobre a conversão alimentar nos animais que consumiram rações com os niveis mais baixos de peróxidos $(0$ ou 2 meq peróxidos $/ \mathrm{kg}$ ), que abrangem os niveis utilizados nesse estudo ( 0 a 0,3 $\mathrm{meq} / \mathrm{kg}$ ). Segundo os autores, somente à medida que os niveis de peróxidos subiram para 4 ou $7 \mathrm{meq} / \mathrm{kg}$ de ração, é que foi possivel identificar alguma depressão significativa no peso vivo dos frangos aos 21 ou 42 dias de idade; além disso, o efeito na conversão alimentar somente foi verificado para os animais que consumiram as rações com os niveis mais elevados de peróxidos ( $7 \mathrm{meq} / \mathrm{kg}$ de ração). Nestes casos, a adição do antioxidante na ração na dosagem de $125 \mathrm{ppm}$ eliminou tais efeitos negativos. Os autores sugerem ainda que o nivel mínimo de peróxidos necessário para causar alterações no desempenho de aves é de $4 \mathrm{meq} / \mathrm{kg}$ de ração. 
O nível máximo de peróxidos utilizado nesse estudo $(0,3 \mathrm{meq} / \mathrm{kg}$ de ração no tratamento CONTROLE) não foi suficiente para produzir efeitos negativos nas variáveis estudadas ( $P V, G P, C R, C A, M R$ e FP). Os únicos efeitos significativos detectados foram reduções no $P V, C R$ e GPD do tratamento $\mathrm{BHT} / 28$ em relação ao CONTROLE, embora os valores de IP desse tratamento tenham sido inferiores ao CONTROLE.

A qualidade da FCO utilizada deve ter sido a causa principal e mais provável dos baixos niveis de peróxidos nas dietas, uma vez que esta matériaprima foi a única fonte destes compostos nas rações.

No início do experimento, tivemos uma grande preocupação com a escolha da FCO a ser utilizada. Procuramos adquiri-la de um fornecedor idôneo, que tomasse os devidos cuidados no transporte e no manuseio da matéria-prima, que fosse criterioso na qualidade do processo de produção, e que estivesse atento aos critérios de limpeza das instalações e equipamentos. Todo esse cuidado resultou num produto de boa qualidade $e$, consequentemente, mais estável.

Outro fator importante foi o armazenamento da FCO, que ocorreu numa época fresca do ano, com temperaturas amenas (Apêndice 7). Como sabemos, temperaturas elevadas aceleram o processo oxidativo; neste caso, as baixas temperaturas ocorridas no período de armazenamento contribuíram para a conservação da FCO em boas condições por mais tempo, resultando numa oxidação lenta e pouco agressiva, tanto que a FCO atingiu niveis de peróxidos considerados baixos (não ultrapassando $80 \mathrm{meq} / \mathrm{kg}$ ), quando comparamos com oxidação de gorduras feita através do aquecimento e aeração, onde o IP pode chegar a $189 \mathrm{meq} / \mathrm{kg}$ (Galvin et al., 1997).

Não podemos nos esquecer também que, conforme destacado anteriormente, os resultados obtidos para as variáveis estudadas peso vivo, ganho de peso e conversão alimentar e, consequentemente, para o fator de produção foram superiores aos padrões da linhagem em todos os tratamentos, 
inclusive no tratamento CONTROLE. Isso pode ter contribuído para diminuir as diferenças na comparação entre os tratamentos. 


\section{CONCLUSÕES}

- A adição de $500 \mathrm{mg}$ de $\mathrm{BHT} / \mathrm{kg}$ de FCO foi efetiva na prevenção da rancidez oxidativa na $\mathrm{FCO}$, quando feita logo após o recebimento da farinha fresca ou depois de 7 dias.

- Nas condições deste estudo, a FCO sem a adição do antioxidante, permaneceu com IP abaixo do padrão máximo permitido (10 meq/kg) por pouco mais de uma semana.

- Após o início do processo oxidativo na FCO, a adição de BHT pode ou não controlar seu avanço, dependendo do grau de oxidação da farinha no momento da adição.

- Niveis de peróxidos próximos de $80 \mathrm{meq} / \mathrm{kg}$ na FCO, correspondendo a 0,3 meq $/ \mathrm{kg}$ nas rações de frangos de corte de 1 a 42 dias, aparentemente não são prejudiciais ao desempenho das aves. Em consequência disso, o tratamento da FCO com 0 antioxidante não trouxe beneficios ao desempenho das aves. 


\section{REFERÊNCIAS BIBLIOGRÁFICAS}

ADAMS, C. A. Nutricines: Food components in health and nutrition. Nottingham: Nottingham University Press, 1999. cap. 2, p. 11-32: Oxidation and antioxidants.

ANDRIGUETTO, J.M.; PERLY, L.; MINARDI, I. et al. Nutrição Animal. 4. ed. São Paulo: Nobel, 1986. 395 p.

ASGHAR, A.; LIN, C. F.; GRAY, J.I.; BUCKLEY, D. J., BOOREN, A. M.; CRACKEL R. L.; FLEGAL, C. J. Influence of oxidised dietary oil and antioxidant supplementation on membrane-bound lipids stability in broiler meat. British Poultry Science, v. 30, p. 815-823, 1989.

BAILEY, C. A.; SRINIVASAN, L. J.; MCGEACHIN, R. B. The effect od ethoxyquim on tissue peroxidation and imune status of single comb white leghorn cockerels. Poultry Science, v. 75, p. 1109-1112, 1996.

BALNAVE, D. Essential fatty acids in poultry nutrition. World's Poultry Science Journal, v. 26, p. 442-460, 1970.

BARTOV, I.; BORNESTEIN, S. Comparisons of BHT and ethoxyquim ans antioxidants in the nutrition of broilers. Poultry Science, v. 51, p. 859-868, 1972. 
BARTOV, I.; BORNESTEIN, S. Stability of abdominal fat and meat of broilers: combined effect of dietary vitamin $E$ and synthetic antioxidants. Poultry Science, v. 60, p. 1840-1845, 1981.

BARTOV, I.; SKLAN, D.; FRIEDMAN, A. Effect of vitamin A on the oxidative stability of broiler meat during storage: lack of interactions with vitamin $E$. British Poultry Science, v. 38, p. 255-257, 1997.

BATTERHAM, E. S.; DARNELL R. E.; HERBERT, L. S.; MAJOR, E. J. Effects of pressure and temperature on the avaiability of lysine in meat and bone meal as determined by slope-ratio assays with growing pigs, rats and chicks and by chemical techniques. British Journal of Nutrition, v. 55, p. 441453, 1986.

CABEL, M. C.; WALDROUP, P. W.; SHERMER, W.; CALABOTTA, D. F. Effects of ethoxiquim feed preservative and peroxide level on broiler performance. Poultry Science, v. 6, p. 1725-1730, 1988.

COMPENDIO brasileiro de nutrição animal. Brasília: Ministério de Agricultura, 1998. $1 \mathrm{v}$.

DIBNER, J. J.; ATWELL, C. A.; KITCHELL, M. L.; SHERMER, W. D.; IVEY, F.J. Feeding of oxidised fats to broilers and swine: effects on enterocyte turnover, hepatocyte proliferation and gut associated lymphoid tissue. Animal feed science and technology, v. 62, p. 1-13, 1996.

DOLZ, S.; DE BLAS, C. Metabolizable energy of meat and bone meal from Spanish rendering plants as influenced by level of substitution and method of determination. Poultry Science, v. 71, p. 316-322, 1992. 
ENGBERG, R. M.; LAURIDSEN, C.; JENSEN, S. K.; JAKOBSEN, K. Inclusion of oxidised vegetable oil in broiler diets. Its influence on nutrient balance and on antioxidative status of broilers. Poultry Science, v. 75, p. 1003-1011, 1996.

FRIEDMAN A.; SKLAN, D. Effect of dietary fatty acids on humoral immune response of turkeys. British Poultry Science, v. 38, p. 342-348, 1997.

GALVIN, K.; MORRISSEY, P.A.; BUCKLEY, D. J. Influence of dietary vitamin E and oxidised sunflower oil on the storage stability of coocked chicken muscle. British Poultry Science, v. 38, p. 499-501, 1997.

GIESE, J. Antioxidants: tools for preventing lipid oxidation. Food Technology, Nov., p. 73-81, 1996.

JONES, F.T., WARD, J.B., BREWER, C.E. Antioxidants use in broilers feeds. Poultry Science, v. 65, p. 779-781, 1986.

KIRKLAND W. M.; FULLER, H. L. The effect of ethoxyquim on the chemical and nutritional changes of poultry by-product meal and poultry offal fat during storage. Poultry Science, v. 50, p. 137-143, 1971.

LIN, C. F.; ASGHAR, A.; GRAY, J.I; BUCKLEY, D. J.; BOOREN, A. M.; CRACKEL, R. L.; FLEGAL, C. J. Effects of oxidised dietary oil and antioxidant supplementation on broiler growth and meat stability. British Poultry Science, v. 30, p. 855-864, 1989.

MARCH, B. E; BIELY, J.; CLAGGETT, F. E.; TARR, H. L. A. Nutritional and chemical changes in the lipid fraction of herring meals with or without antioxidant treatment. Poultry Science, v. 40, p. 873-880, 1961. 
MAYNARD, L.A.; LOOSLI, J.K.; HINTZ, H.F. Nutrição Animal. 3. ed. Rio de Janeiro: Freitas Bastos, 1984. 726 p.

McKNIGHT, W. F. Effect of antioxidant vitamins on broiler meat quality. In: BASF TECHNICAL SYMPOSIUM, Atlanta, 1996. Anais. Atlanta: BASF (ed.), 1996, p. 67-96.

NATIONAL RESEARCH CONCIL. Nutrient requirements of poultry. 9. ed. Washington, D. C.: National Academy Press, 1994. 71p.

PARSONS, C.M., CASTANON, F., HAN, Y. Protein and amino acid quality of meat and bone meal. Poultry Science, v. 76, p. 361-368, 1997.

QUIÑNONES, J.P. Antioxidantes usados em alimentos. Revista Óleos e Grãos, Jan./Fev., p. 39-42, 1995.

ROBEY, W. Preventing the negative effects of nutrient oxidation on animal nutrition and performance. Novus - Nutrition Update, v. 4, n. 2, 1994.

ROBEY, W.; SHERMER, W. The damaging effects of oxidation. Feed Mix, v. 2, n. 5, p. 22-26, 1994.

ROSTAGNO, H. S.; BARBARINO Jr. P.; BARBOSA, W. A. Exigências nutricionais das aves determinadas no Brasil. In: SIMPÓSIO INTERNACIONAL SOBRE EXIGENNCIAS NUTRICIONAIS DE AVES E SUÍNOS, Viçosa, 1996. Anais. Viçosa: Rostagno, H.S. (ed.), 1996. p. 361388. 
RUNNELS, T. D.; KOBRIN, B. R.; ELY, C. M. The relative effect of ethoxyquim versus B.H.T. on broiler performance and pigmentation. Poultry Science, v. 45, p. $1283-1290,1966$.

SANZ, M.; FLORES, A.; LOPEZ-BOTE, C. J. Effect of fatty acid saturation in broiler ciets on abdominal fat and breast muscle fatty acid composition and susceptibility to lipid oxidation. Poultry Science, v. 78, p. 378-382, 1999.

SAS INSTITUTE. SAS/STAT: user's Guide, version 6.Cary, 1989. 1686 p.

SCOTT, M.L.; NESHEIN, M.C.; YOUNG, R.J. Nutrition of the Chicken. 3. ed. Ithaca: M.L. Scott \& Associates, 1982. 562 p.

SELL, J.L. Influence of dietary concentration and source of meat and bone meal on performance of turkeys. Poultry Science, v. 75, p.1076-1079, 1996.

SHELDON, B. W.; CURTIS, P. A.; DAWSON, P. L.; FERKET, P. R. Effect of dietary vitamin $E$ on the oxidative stability, flavor, color, and volatile profiles of refrigerated and frozen turkey breast meat. Poultry Science, v. 76, p. 634-641, 1997.

SHERMER, W. D. \& CALABOTTA, D. F. Oxidation of feed: How much has occured? Feedstuffs, v4, p. 19-20, 1985.

SURAK, J. C.; BRADLEY JR., R. L.; MAURER, A. J.; RIBELIN, W. E. Butylated hydroxyanisole (BHA) and butylated hydroxytoluene (BHT) effects on serun and liver lipid levels in gallus domesticus. Poultry Science, v. 56, p. 747753, 1977. 
VALENZUELA, A. B.; NIETO, S. K. Los antioxidantes: protectores de la calidad en la industria alimentaria. Aceites y Grasas, Set., p. 310-321, 1995.

WALDROUP, P.W., ADAMS, M.H. Evaluation of the phosphorus provided by animal proteins in the diet of broiler chickens. Journal Applied of Poultry Research., v. 3, p. 209-218, 1994.

WALDROUP, P. W.; DOUGLAS, C. R.; MCCALL, J. T.; HARMS, R. H. The effects os Santoquim $\otimes$ on the performance of broilers. Poultry Science, v. 39 , p. 1313-1317, 1960.

WALDROUP, P. W.; MABRAY, C. J.; BLACKMAN, J. R.; SHORT, J. R.; RAMSEY, B. E.; JOHNSON, Z. B. A comparison of the effectiveness of different antioxidants in broiler diets. Nutrition Reports International, v. 24, n. 3, p. 591-602, 1981.

WANG, SUI-YING; BOTTJE, W.; MAYNARD, P.; DIBNER, J.; SHERMER, W. Effect of Santoquim ${ }^{\circledR}$ and oxidysed fat on liver and intestinal glutatione in broilers. Poultry Science, v. 76, p. 961-967, 1997.

WANG, X.; CASTANON, F.; PARSONS, C. M. Order of amino acid limitation in meat and bone meal. Poultry Science, v. 76, p. 54-58, 1997.

WANG, X.; PARSONS, C. M. Bioavaiability of the digestible lysine and total sulfur amino acids in meat and bone meal varying in protein quality. Poultry Science, v. 77, p. 1003-1009, 1998a.

WANG, X.; PARSONS, C. M. Dietary formulation with meat and bone meal on a total versus a digestible or bioavailable amino acids basis. Poultry Science, v. 77 , p. 1010-1015, $1998 \mathrm{~b}$. 
WANG, X.; PARSONS, C. M. Effect of raw material source, processing systems, and processing temperatures on amino acid digestibility of meat and bone meals. Poultry Science, v. 77, p. 834-841, 1998c.

WATKINS, B. A. Essential fatty acids in poultry nutrition: their importance, metabolic and physiological significance and feeding considerations. Novus-Nutrition Update, v. 1, n. 1, 1991. 
APÊNDICE 
Apêndice 1. Peso vivo médio $(\mathrm{kg})$ das aves obtido semanalmente.

\begin{tabular}{|c|c|c|c|c|c|c|c|}
\hline \multirow{2}{*}{ TRATAMENTO } & \multicolumn{7}{|c|}{ DIAS } \\
\hline & 1 & 7 & 14 & 21 & 28 & 35 & 42 \\
\hline \multirow{6}{*}{ CONTROLE } & 0,040 & 0,153 & 0,418 & 0,863 & 1,305 & 1,913 & 2,577 \\
\hline & 0,039 & 0,143 & 0,408 & 0,849 & 1,316 & 1,943 & 2,600 \\
\hline & 0,039 & 0,147 & 0,418 & 0,856 & 1,339 & 1,947 & 2,626 \\
\hline & 0,041 & 0,145 & 0,403 & 0,866 & 1,350 & 1,942 & 2,616 \\
\hline & 0,040 & 0,148 & 0,415 & 0,853 & 1,344 & 1,961 & 2,645 \\
\hline & 0,040 & 0,149 & 0,428 & 0,872 & 1,328 & 1,936 & 2,592 \\
\hline MÉDIA & 0,040 & 0,147 & 0,415 & 0,860 & 1,330 & 1,940 & 2,609 \\
\hline \multirow{6}{*}{ BHT/O } & 0,039 & 0,143 & 0,400 & 0,833 & 1,290 & 1,895 & 2,585 \\
\hline & 0,040 & 0,143 & 0,400 & 0,838 & 1,283 & 1,885 & 2,505 \\
\hline & 0,041 & 0,148 & 0,408 & 0,838 & 1,290 & 1,883 & 2,540 \\
\hline & 0,040 & 0,143 & 0,405 & 0,850 & 1,350 & 1,953 & 2,700 \\
\hline & 0,038 & 0,142 & 0,393 & 0,815 & 1,295 & 1,890 & 2,574 \\
\hline & 0,039 & 0,139 & 0,393 & 0,838 & 1,316 & 1,923 & 2,615 \\
\hline MÉDIA & 0,039 & 0,143 & 0,400 & 0,835 & 1,304 & 1,905 & 2,587 \\
\hline \multirow{6}{*}{ BHT/7 } & 0,040 & 0,144 & 0,408 & 0,858 & 1,338 & 1,947 & 2,614 \\
\hline & 0,039 & 0,145 & 0,408 & 0,851 & 1,318 & 1,951 & 2,639 \\
\hline & 0,040 & 0,148 & 0,415 & 0,854 & 1,349 & 1,949 & 2,649 \\
\hline & 0,040 & 0,148 & 0,413 & 0,854 & 1,362 & 1,984 & 2,700 \\
\hline & 0,040 & 0,144 & 0,405 & 0,850 & 1,353 & 1,969 & 2,672 \\
\hline & 0,040 & 0,149 & 0,403 & 0,871 & 1,363 & 1,982 & 2,695 \\
\hline MÉDIA & 0,040 & 0,146 & 0,409 & 0,856 & 1,347 & 1,964 & 2,662 \\
\hline \multirow{6}{*}{ BHT/14 } & 0,040 & 0,145 & 0,415 & 0,855 & 1,325 & 1,920 & 2,585 \\
\hline & 0,039 & 0,144 & 0,400 & 0,815 & 1,277 & 1,885 & 2,567 \\
\hline & 0,041 & 0,147 & 0,415 & 0,867 & 1,351 & 1,947 & 2,619 \\
\hline & 0,040 & 0,144 & 0,403 & 0,833 & 1,318 & 1,925 & 2,636 \\
\hline & 0,040 & 0,143 & 0,395 & 0,813 & 1,311 & 1,946 & 2,632 \\
\hline & 0,040 & 0,146 & 0,410 & 0,849 & 1,333 & 1,933 & 2,613 \\
\hline MÉDIA & 0,040 & 0,145 & 0,406 & 0,838 & 1,319 & 1,926 & 2,609 \\
\hline \multirow{6}{*}{$\mathrm{BHT} / 21$} & 0,039 & 0,144 & 0,403 & 0,844 & 1,318 & 1,948 & 2,631 \\
\hline & 0,039 & 0,139 & 0,388 & 0,821 & 1,279 & 1,915 & 2,582 \\
\hline & 0,040 & 0,142 & 0,398 & 0,831 & 1,282 & 1,913 & 2,584 \\
\hline & 0,040 & 0,142 & 0,395 & 0,826 & 1,277 & 1,914 & 2,647 \\
\hline & 0,040 & 0,145 & 0,400 & 0,818 & 1,268 & 1,916 & 2,624 \\
\hline & 0,040 & 0,144 & 0,400 & 0,843 & 1.349 & 1,962 & 2,614 \\
\hline MÉDIA & 0,040 & 0,143 & 0,397 & 0,830 & 1,295 & 1,928 & 2,618 \\
\hline \multirow{6}{*}{$\mathrm{BHT} / 28$} & 0,039 & 0,143 & 0,398 & 0,812 & 1,265 & 1,848 & 2,483 \\
\hline & 0,039 & 0,141 & 0,395 & 0,815 & 1,269 & 1,869 & 2,500 \\
\hline & 0,040 & 0,137 & 0,393 & 0,818 & 1,305 & 1,893 & 2,556 \\
\hline & 0,040 & 0,141 & 0,395 & 0,826 & 1,345 & 1,963 & 2,618 \\
\hline & 0,039 & 0,143 & 0,403 & 0,838 & 1,333 & 1,958 & 2,633 \\
\hline & 0,039 & 0,146 & 0,398 & 0,823 & 1,262 & 1,837 & 2,424 \\
\hline MÉDIA & 0,039 & 0,142 & 0,397 & 0,822 & 1,296 & 1,894 & 2,536 \\
\hline
\end{tabular}


Apêndice 2. Ganho médio de peso acumulado $(\mathrm{kg})$ das aves.

\begin{tabular}{|c|c|c|c|c|c|c|}
\hline \multirow{2}{*}{ TRATAMENTO } & \multicolumn{6}{|c|}{ DIAS } \\
\hline & 7 & 14 & 21 & 28 & 35 & 42 \\
\hline \multirow{6}{*}{ CONTROLE } & 0,113 & 0,378 & 0,823 & 1,265 & 1,873 & 2,537 \\
\hline & 0,104 & 0,369 & 0,810 & 1,277 & 1,904 & 2,561 \\
\hline & 0,108 & 0,379 & 0,817 & 1,300 & 1,908 & 2,587 \\
\hline & 0,104 & 0,362 & 0,825 & 1,310 & 1,902 & 2,575 \\
\hline & 0,108 & 0,375 & 0,813 & 1,304 & 1,921 & 2,605 \\
\hline & 0,110 & 0,388 & 0,832 & 1,289 & 1,896 & 2,553 \\
\hline MÉDIA & 0,108 & 0,375 & 0,820 & 1,291 & 1,901 & 2,570 \\
\hline \multirow{6}{*}{ BHTIO } & 0,104 & 0,361 & 0,794 & 1,251 & 1,856 & 2,546 \\
\hline & 0,103 & 0,360 & 0,798 & 1,243 & 1,845 & 2,465 \\
\hline & 0,107 & 0,367 & 0,797 & 1,250 & 1,842 & 2,500 \\
\hline & 0,103 & 0,366 & 0,811 & 1,311 & 1,913 & 2,658 \\
\hline & 0,104 & 0,351 & 0,773 & 1,253 & 1,848 & 2,533 \\
\hline & 0,100 & 0,353 & 0,799 & 1,277 & 1,884 & 2,576 \\
\hline MÉDIA & 0,104 & 0,360 & 0,795 & 1,264 & 1,865 & 2,546 \\
\hline \multirow{6}{*}{ BHT/7 } & 0,105 & 0,368 & 0,818 & 1,298 & 1,908 & 2,575 \\
\hline & 0,106 & 0,369 & 0,812 & 1,279 & 1,912 & 2,600 \\
\hline & 0,108 & 0,375 & 0,814 & 1,309 & 1,909 & 2,609 \\
\hline & 0,108 & 0,373 & 0,814 & 1,322 & 1,944 & 2,660 \\
\hline & 0,105 & 0,365 & 0,810 & 1,313 & 1,930 & 2,632 \\
\hline & 0,109 & 0,363 & 0,831 & 1,323 & 1,942 & 2,655 \\
\hline MÉDIA & 0,107 & 0,369 & 0,817 & 1,307 & 1,924 & 2,622 \\
\hline \multirow{6}{*}{ BHT/14 } & 0,105 & 0,375 & 0,815 & 1,285 & 1,880 & 2,545 \\
\hline & 0,104 & 0,361 & 0,776 & 1,238 & 1,845 & 2,527 \\
\hline & 0,107 & 0,375 & 0,826 & 1,311 & 1,907 & 2,578 \\
\hline & 0,105 & 0,363 & 0,793 & 1,278 & 1,886 & 2,596 \\
\hline & 0,103 & 0,356 & 0,773 & 1,271 & 1,906 & 2,593 \\
\hline & 0,106 & 0,370 & 0,808 & 1,293 & 1,893 & 2,572 \\
\hline MÉDIA & 0,105 & 0,366 & 0,799 & 1,279 & 1,886 & 2,569 \\
\hline \multirow{6}{*}{ BHT/21 } & 0,105 & 0,363 & 0,804 & 1,278 & 1,908 & 2,592 \\
\hline & 0,100 & 0,348 & 0,781 & 1,240 & 1,876 & 2,543 \\
\hline & 0,102 & 0,358 & 0,791 & 1,243 & 1,874 & 2,545 \\
\hline & 0,102 & 0,355 & 0,785 & 1,237 & 1,878 & 2,612 \\
\hline & 0,105 & 0,360 & 0,778 & 1,228 & 1,876 & 2,584 \\
\hline & 0,104 & 0,360 & 0,802 & 1,308 & 1,955 & 2,634 \\
\hline MÉDIA & 0,103 & 0,357 & 0,790 & 1,256 & 1,895 & 2,585 \\
\hline \multirow{6}{*}{ BHT/28 } & 0,105 & 0,359 & 0,773 & 1,226 & 1,809 & 2,444 \\
\hline & 0,102 & 0,356 & 0,776 & 1,230 & 1,830 & 2,461 \\
\hline & 0,098 & 0,353 & 0,778 & 1,265 & 1,853 & 2,517 \\
\hline & 0,101 & 0,355 & 0,786 & 1,305 & 1,923 & 2,578 \\
\hline & 0,104 & 0,363 & 0,798 & 1,293 & 1,918 & 2,593 \\
\hline & 0,107 & 0,358 & 0,784 & 1,222 & 1,798 & 2,384 \\
\hline MÉDIA & 0,103 & 0,357 & 0,783 & 1,257 & 1,855 & 2,496 \\
\hline
\end{tabular}


Apêndice 3. Consumo de ração médio corrigido e acumulado $(\mathrm{kg})$ das aves.

\begin{tabular}{|c|c|c|c|c|c|c|}
\hline \multirow{2}{*}{ TRATAMENTO } & \multicolumn{6}{|c|}{ DIAS } \\
\hline & 7 & 14 & 21 & 28 & 35 & 42 \\
\hline \multirow{6}{*}{ CONTROLE } & 0,133 & 0,500 & 1,162 & 2,024 & 3,077 & 4,444 \\
\hline & 0,127 & 0,494 & 1,200 & 2,079 & 3,197 & 4,570 \\
\hline & 0,128 & 0,495 & 1,136 & 2,024 & 3,134 & 4,534 \\
\hline & 0,132 & 0,470 & 1,155 & 2,003 & 3,099 & 4,465 \\
\hline & 0,128 & 0,506 & 1,186 & 2,078 & 3,212 & 4,610 \\
\hline & 0,125 & 0,495 & 1,159 & 2,003 & 3,114 & 4,482 \\
\hline MÉDIA & 0,129 & 0,493 & 1,166 & 2,035 & 3,139 & 4,517 \\
\hline \multirow{6}{*}{ BHT/O } & 0,135 & 0,497 & 1,165 & 2,000 & 3,100 & 4,482 \\
\hline & 0,129 & 0,474 & 1,119 & 1,934 & 2,998 & 4,307 \\
\hline & 0,128 & 0,489 & 1,157 & 1,979 & 3,070 & 4,402 \\
\hline & 0,129 & 0,475 & 1,132 & 1,985 & 3,096 & 4,645 \\
\hline & 0,126 & 0,480 & 1,178 & 2,030 & 3,103 & 4,497 \\
\hline & 0,124 & 0,495 & 1,206 & 2,117 & 3,201 & 4,624 \\
\hline MÉDIA & 0,128 & 0,485 & 1,159 & 2,007 & 3,094 & 4,493 \\
\hline \multirow{6}{*}{ ВHT/7 } & 0,130 & 0,483 & 1,144 & 1,997 & 3,133 & 4,527 \\
\hline & 0,125 & 0,487 & 1,192 & 2,038 & 3,170 & 4,593 \\
\hline & 0,139 & 0,485 & 1,165 & 2,041 & 3,128 & 4,550 \\
\hline & 0,131 & 0,507 & 1,217 & 2,144 & 3,280 & 4,720 \\
\hline & 0,122 & 0,476 & 1,127 & 2,000 & 3,115 & 4,531 \\
\hline & 0,129 & 0,485 & 1,210 & 2,099 & 3,236 & 4,668 \\
\hline MÉDIA & 0,129 & 0,487 & 1,176 & 2,053 & 3,177 & 4,598 \\
\hline \multirow{6}{*}{ BHT/14 } & 0,126 & 0,488 & 1,155 & 2,008 & 3,072 & 4,422 \\
\hline & 0,128 & 0,490 & 1,145 & 2,003 & 3,087 & 4,490 \\
\hline & 0,131 & 0,490 & 1,153 & 2,002 & 3,111 & 4,460 \\
\hline & 0,131 & 0,494 & 1,149 & 1,989 & 3,094 & 4,506 \\
\hline & 0,127 & 0,473 & 1,098 & 1,988 & 3,117 & 4,527 \\
\hline & 0,145 & 0,509 & 1,175 & 2,034 & 3,124 & 4,491 \\
\hline MÉDIA & 0,131 & 0,491 & 1,146 & 2,004 & 3,101 & 4,483 \\
\hline \multirow{6}{*}{$\mathrm{BHT} / 21$} & 0,125 & 0,471 & 1,143 & 1,952 & 3,118 & 4,553 \\
\hline & 0,131 & 0,479 & 1,186 & 2,014 & 3,108 & 4,482 \\
\hline & 0,119 & 0,466 & 1,145 & 1,971 & 3,096 & 4,477 \\
\hline & 0,125 & 0,486 & 1,232 & 2,055 & 3,221 & 4,703 \\
\hline & 0,128 & 0,481 & 1,131 & 1,951 & 3,108 & 4,542 \\
\hline & 0,144 & 0,500 & 1,155 & 2,015 & 3,211 & 4,629 \\
\hline MÉDIA & 0,129 & 0,480 & 1,165 & 1,993 & 3,144 & 4,565 \\
\hline \multirow{6}{*}{ BHT/28 } & 0,153 & 0,470 & 1,077 & 1,918 & 2,946 & 4,261 \\
\hline & 0,123 & 0,479 & 1,120 & 1,946 & 3,017 & 4,337 \\
\hline & 0,124 & 0,470 & 1,097 & 1,935 & 3,029 & 4,398 \\
\hline & 0,121 & 0,483 & 1,134 & 2,023 & 3,147 & 4,526 \\
\hline & 0,127 & 0,481 & 1,133 & 1,986 & 3,124 & 4,479 \\
\hline & 0,125 & 0,480 & 1,135 & 1,951 & 3,002 & 4,247 \\
\hline MÉDIA & 0,129 & 0,477 & 1,116 & 1,960 & 3,044 & 4,375 \\
\hline
\end{tabular}


Apêndice 4. Conversão alimentar média acumulada das aves.

\begin{tabular}{|c|c|c|c|c|c|c|}
\hline \multirow{2}{*}{ TRATAMENTO } & \multicolumn{6}{|c|}{ DIAS } \\
\hline & 7 & 14 & 21 & 28 & 35 & 42 \\
\hline \multirow{6}{*}{ CONTROLE } & 1,170 & 1,323 & 1,413 & 1,600 & 1,643 & 1,751 \\
\hline & 1,229 & 1,338 & 1,483 & 1,628 & 1,679 & 1,784 \\
\hline & 1,191 & 1,306 & 1,390 & 1,557 & 1,642 & 1,752 \\
\hline & 1,269 & 1,299 & 1,400 & 1,529 & 1,630 & 1,734 \\
\hline & 1,180 & 1,347 & 1,459 & 1,594 & 1,672 & 1,770 \\
\hline & 1,137 & 1,276 & 1,393 & 1,554 & 1,642 & 1,756 \\
\hline MÉDIA & 1,196 & 1,315 & 1,423 & 1,577 & 1,651 & 1,758 \\
\hline \multirow{6}{*}{ BHT/O } & 1,301 & 1,377 & 1,468 & 1,599 & 1,670 & 1,761 \\
\hline & 1,252 & 1,314 & 1,402 & 1,556 & 1,624 & 1,747 \\
\hline & 1,191 & 1,333 & 1,451 & 1,584 & 1,667 & 1,761 \\
\hline & 1,249 & 1,299 & 1,397 & 1,514 & 1,619 & 1,748 \\
\hline & 1,208 & 1,369 & 1,524 & 1,619 & 1,679 & 1,776 \\
\hline & 1,241 & 1,400 & 1,509 & 1,658 & 1,699 & 1,795 \\
\hline MÉDIA & 1,241 & 1,349 & 1,459 & 1,588 & 1,660 & 1,765 \\
\hline \multirow{6}{*}{ BHT/7 } & 1,239 & 1,312 & 1,398 & 1,538 & 1,642 & 1,758 \\
\hline & 1,174 & 1,320 & 1,467 & 1,594 & 1,658 & 1,766 \\
\hline & 1,282 & 1,292 & 1,431 & 1,560 & 1,639 & 1,744 \\
\hline & 1,216 & 1,360 & 1,496 & 1,622 & 1,687 & 1,774 \\
\hline & 1,165 & 1,302 & 1,390 & 1,523 & 1,614 & 1,721 \\
\hline & 1,186 & 1,337 & 1,455 & 1,586 & 1,667 & 1,758 \\
\hline MÉDIA & 1,211 & 1,320 & 1,440 & 1,570 & 1,651 & 1,754 \\
\hline \multirow{6}{*}{ BHT/14 } & 1,200 & 1,301 & 1,417 & 1,562 & 1,634 & 1,738 \\
\hline & 1,235 & 1,358 & 1,476 & 1,619 & 1,673 & 1,776 \\
\hline & 1,222 & 1,308 & 1,396 & 1,527 & 1,632 & 1,730 \\
\hline & 1,256 & 1,360 & 1,449 & 1,556 & 1,641 & 1,735 \\
\hline & 1,225 & 1,330 & 1,419 & 1,563 & 1,635 & 1,746 \\
\hline & 1,362 & 1,378 & 1,454 & 1,573 & 1,651 & 1,746 \\
\hline MÉDIA & 1,250 & 1,339 & 1,435 & 1,567 & 1,644 & 1,745 \\
\hline \multirow{6}{*}{ BHT/21 } & 1,196 & 1,296 & 1,421 & 1,527 & 1,634 & 1,757 \\
\hline & 1,313 & 1,375 & 1,518 & 1,624 & 1,656 & 1,763 \\
\hline & 1,167 & 1,300 & 1,447 & 1,586 & 1,652 & 1,759 \\
\hline & 1,221 & 1,370 & 1,569 & 1,662 & 1,715 & 1,800 \\
\hline & 1,220 & 1,335 & 1,454 & 1,589 & 1,657 & 1,758 \\
\hline & 1,387 & 1,390 & 1,440 & 1,540 & 1,643 & 1,757 \\
\hline MÉDIA & 1,251 & 1,344 & 1,475 & 1,588 & 1,659 & 1,766 \\
\hline \multirow{6}{*}{$\mathrm{BHT} / 28$} & 1,464 & 1,309 & 1,393 & 1,564 & 1,629 & 1,744 \\
\hline & 1,200 & 1,347 & 1,443 & 1,582 & 1,648 & 1,762 \\
\hline & 1,269 & 1,332 & 1,411 & 1,529 & 1,635 & 1,748 \\
\hline & 1,203 & 1,360 & 1,443 & 1,550 & 1,636 & 1,755 \\
\hline & 1,219 & 1,323 & 1,419 & 1,535 & 1,628 & 1,727 \\
\hline & 1,166 & 1,339 & 1,448 & 1,596 & 1,670 & 1,781 \\
\hline MÉDIA & 1,254 & 1,335 & 1,426 & 1,559 & 1,641 & 1,753 \\
\hline
\end{tabular}


Apêndice 5. Mortalidade (M) e refugagem (R) das aves de 1 a 42 dias.

\begin{tabular}{|c|c|c|c|c|c|c|c|}
\hline \multirow{3}{*}{ TRATAMENTO } & \multicolumn{7}{|c|}{ DIAS } \\
\hline & 7 & 14 & \multirow{2}{*}{\begin{tabular}{l|l}
21 \\
$M$
\end{tabular}} & 28 & 35 & \multicolumn{2}{|l|}{42} \\
\hline & $M \quad R$ & $M \quad R$ & & $M \quad R$ & & $M \quad R$ & \\
\hline \multirow{4}{*}{ CONTROLE } & - & 9 & & 1 & 1 & 1 & 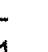 \\
\hline & - & 1 & $\begin{array}{l}2 \\
1\end{array}$ & 2 & 2 & 2 & $\frac{T}{1}$ \\
\hline & & - & & 2 & 2 & - & 2 \\
\hline & - & - & & 1 & 2 & 2 & \\
\hline \multirow{2}{*}{$\begin{array}{cc}n^{\circ} \text { aves } \\
\%\end{array}$} & \multirow{2}{*}{$\begin{array}{l}0 \\
0\end{array}$} & \multirow{2}{*}{3} & 7 & 10 & 11 & 12 & \\
\hline & & & $\frac{7}{2.91}$ & 4,17 & 4,58 & \multicolumn{2}{|l|}{5,0} \\
\hline \multirow{5}{*}{ BHT/O } & & & & $-\quad-$ & $1-$ & $1-$ & \\
\hline & - & - & - & - & - & 1 & \\
\hline & - & 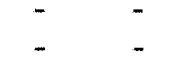 & $=$ & - & $=$ & $\overline{2}$ & 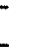 \\
\hline & - & & & 1 & 1 & 1 & \\
\hline & - & - & $1-$ & $1-$ & & $1-$ & \\
\hline \multirow{2}{*}{ TOTAL $\begin{array}{c}N^{\circ} \text { aves } \\
\%\end{array}$} & 0 & 0 & 1 & $\frac{2}{083}$ & $\frac{3}{125}$ & $\frac{7}{291}$ & \\
\hline & - & 1 & & 2,00 & & & 1 \\
\hline & & & & 1 & 1 & 1 & \\
\hline BHT/7 & - & 1 & 1 & 1 & 1 & 1 & 2 \\
\hline & - & 1 & 1 & 2 & 2 & 2 & 1 \\
\hline & - & 1 & $\begin{array}{l}2 \\
1\end{array}$ & $\begin{array}{l}3 \\
1\end{array}$ & 3 & $\begin{array}{l}3 \\
1\end{array}$ & 1 \\
\hline TOTAL $\mathbf{N}^{\circ}$ aves & 0 & 4 & 9 & 16 & 17 & 19 & \\
\hline IUIAL \% & 0 & 1,67 & 3,75 & 6,67 & 7,08 & 7,92 & \\
\hline & - & & $-\quad-$ & & $-\quad \overline{1}-$ & & \\
\hline & & & & 1 & & & \\
\hline BHT/14 & - & & & & & 1 & - \\
\hline & - & & 1 & 1 & & 1 & 2 \\
\hline$N^{\circ}$ aves & $-\frac{-}{-}$ & -0 & $1-$ & $\frac{1}{6}$ & $17-$ & 1 & \\
\hline TOTAL $\begin{array}{c}N \text { aves } \\
\%\end{array}$ & 0 & 0 & $\frac{3}{1,25}$ & $\frac{0}{2,50}$ & $\frac{1}{2,91}$ & 3,75 & \\
\hline & - & - & & & & & \\
\hline & - & - & 1 & 1 & 1 & 1 & \\
\hline BHT/21 & - & - & 1 & 1 & 2 & 2 & \\
\hline & - & & & 1 & & 2 & \\
\hline & - & - & & 1 & 1 & $1-$ & \\
\hline TOTAL $n^{\circ}$ aves & 0 & 0 & 3 & 4 & 9 & 11 & \\
\hline WIAL $\%$ & 0 & 0 & 1,25 & 1,67 & 3,75 & 4,58 & \\
\hline & 5 & $i$ & - & - & $i$ & & \\
\hline BHT/28 & - & - & & & - & 1 & \\
\hline & - & 1 & & & 1 & 1 & \\
\hline & $\therefore$ & $-\quad-$ & $i$ & & 25 & 2 & \\
\hline TOTAL $n^{\circ}$ aves & 0 & 2 & 3 & 4 & 5 & 7 & \\
\hline TUTAL & 0 & 0,83 & 1,25 & 1,67 & 2,08 & 2,91 & \\
\hline
\end{tabular}


Apêndice 6. Temperaturas máximas e minimas observadas diariamente no aviário durante o período experimental ( 1 a 42 dias).

\begin{tabular}{|c|c|c|c|c|}
\hline \multirow[t]{2}{*}{ DATA } & \multicolumn{2}{|c|}{ TERMÔMETRO 1} & \multicolumn{2}{|c|}{ TERMÓMETRO 2} \\
\hline & MIN. $\left({ }^{\circ} \mathrm{C}\right)$ & MÁX. $\left({ }^{\circ} \mathrm{C}\right)$ & MíN. $\left({ }^{\circ} \mathrm{C}\right)$ & MÁX. $\left({ }^{\circ} \mathrm{C}\right)$ \\
\hline $\begin{array}{l}a / n \Delta / 9 a \\
30 / 04 / 99 \\
01 / 05 / 99 \\
02 / 05 / 99 \\
03 / 05 / 99 \\
04 / 05 / 99 \\
05 / 05 / 99 \\
06 / 05 / 99 \\
07 / 05 / 99 \\
08 / 05 / 99 \\
09 / 05 / 99 \\
10 / 05 / 99 \\
11 / 05 / 99 \\
12 / 05 / 99 \\
13 / 05 / 99 \\
14 / 05 / 99 \\
15 / 05 / 99 \\
16 / 05 / 99 \\
17 / 05 / 99 \\
18 / 05 / 99 \\
19 / 05 / 99 \\
20 / 05 / 99 \\
21 / 05 / 99 \\
22 / 105 / 99 \\
2305 / 99 \\
24 / 05 / 99 \\
25 / 05 / 99 \\
26 / 05 / 99 \\
27 / 05 / 99 \\
28 / 05 / 99 \\
29 / 05 / 99 \\
30 / 0599 \\
31 / 05 / 99 \\
01 / 06 / 99 \\
02 / 06 / 99 \\
03 / 06 / 99 \\
04 / 06 / 99 \\
05 / 06 / 99 \\
06 / 06 / 99 \\
07 / 06 / 99 \\
08 / 06 / 99 \\
09 / 06 / 99 \\
10 / 06 / 99 \\
\end{array}$ & $\begin{array}{l}14 \\
20 \\
19 \\
18 \\
18 \\
17 \\
18 \\
19 \\
19 \\
17 \\
18 \\
18 \\
19 \\
17 \\
14 \\
15 \\
13 \\
11 \\
15 \\
17 \\
17 \\
11 \\
12 \\
13 \\
14 \\
14 \\
14 \\
16 \\
17 \\
17 \\
18 \\
10 \\
09 \\
10 \\
13 \\
14 \\
18 \\
17 \\
14 \\
17 \\
15 \\
18 \\
18 \\
\end{array}$ & $\begin{array}{l}29 \\
32 \\
32 \\
33 \\
32 \\
32 \\
32 \\
29 \\
27 \\
28 \\
29 \\
28 \\
25 \\
28 \\
28 \\
27 \\
28 \\
29 \\
28 \\
29 \\
28 \\
24 \\
25 \\
24 \\
23 \\
24 \\
22 \\
28 \\
28 \\
26 \\
28 \\
23 \\
21 \\
24 \\
28 \\
27 \\
24 \\
28 \\
21 \\
24 \\
27 \\
28 \\
24 \\
\end{array}$ & $\begin{array}{l}17 \\
21 \\
19 \\
17 \\
21 \\
20 \\
21 \\
21 \\
21 \\
18 \\
21 \\
21 \\
20 \\
20 \\
17 \\
17 \\
16 \\
17 \\
17 \\
17 \\
17 \\
11 \\
11 \\
12 \\
12 \\
13 \\
14 \\
20 \\
20 \\
20 \\
19 \\
11 \\
12 \\
12 \\
14 \\
15 \\
18 \\
16 \\
15 \\
17 \\
16 \\
19 \\
18 \\
\end{array}$ & $\begin{array}{l}0 \\
30 \\
30 \\
30 \\
30 \\
30 \\
30 \\
25 \\
25 \\
25 \\
26 \\
26 \\
23 \\
25 \\
26 \\
24 \\
25 \\
25 \\
25 \\
26 \\
25 \\
21 \\
22 \\
22 \\
22 \\
23 \\
22 \\
26 \\
26 \\
25 \\
26 \\
19 \\
19 \\
21 \\
25 \\
24 \\
22 \\
24 \\
20 \\
21 \\
25 \\
24 \\
21 \\
\end{array}$ \\
\hline
\end{tabular}


Apêndice 7. Temperaturas mínima e máxima e umidade relativa do ar obtidas em leituras diárias durante o periodo de armazenamento da FCO.

\begin{tabular}{|c|c|c|c|c|}
\hline \multirow{2}{*}{ DATA } & \multicolumn{2}{|c|}{ TEMPERATURA } & \multicolumn{2}{|c|}{ UMIDADE RELATIVA } \\
\hline & MiN. $\left({ }^{\circ} \mathrm{C}\right)$ & MÁX. $\left({ }^{\circ} \mathrm{C}\right)$ & MíN. $(\%)$ & MÁX. (\%) \\
\hline $07 / 04 / 99$ & 25,3 & 32,1 & 55 & 76 \\
\hline 08/04/99 & 24,5 & 29,1 & 57 & 77 \\
\hline $09 / 04 / 99$ & 24,5 & 27,5 & 60 & 69 \\
\hline $10 / 04 / 99$ & 22,8 & 27,4 & 55 & 64 \\
\hline $11 / 04 / 99$ & 22,6 & 26,0 & 55 & 62 \\
\hline $12 / 04 / 99$ & 22,1 & 25,9 & 57 & 67 \\
\hline $13 / 04 / 99$ & 23,4 & 27,4 & 59 & 78 \\
\hline $14 / 04 / 99$ & 22,4 & 27,9 & 66 & 88 \\
\hline $15 / 04 / 99$ & 22,9 & 28,6 & 62 & 79 \\
\hline $16 / 04 / 99$ & 21,3 & 24,9 & 74 & 86 \\
\hline $17 / 04 / 99$ & 17,4 & 23,1 & 47 & 80 \\
\hline $18 / 04 / 99$ & 13,4 & 21,9 & 46 & 68 \\
\hline $19 / 04 / 99$ & 13,4 & 20,9 & 49 & 74 \\
\hline $20 / 04 / 99$ & 13,0 & 28,8 & 48 & 79 \\
\hline $21 / 04 / 99$ & 17,5 & 29,9 & 46 & 79 \\
\hline $22 / 04 / 99$ & 19,3 & 27,5 & 51 & 80 \\
\hline $23 / 04 / 99$ & 20,1 & 27,9 & 53 & 73 \\
\hline $24 / 04 / 99$ & 17,6 & 26,9 & 53 & 75 \\
\hline $25 / 04 / 99$ & 18,1 & 25,9 & 53 & 79 \\
\hline 26/04/99 & 17,0 & 25,1 & 48 & 89 \\
\hline 27/04/99 & 18,4 & 25,9 & 47 & 79 \\
\hline $28 / 04 / 99$ & 18,9 & 26,9 & 49 & 82 \\
\hline $29 / 04 / 99$ & 18,6 & 26,1 & 50 & 78 \\
\hline $30 / 04 / 99$ & 19,4 & 26,8 & 48 & 76 \\
\hline $01 / 05 / 99$ & 19,5 & 28,9 & 46 & 74 \\
\hline 02/05/99 & 17,9 & 27,1 & 46 & 80 \\
\hline $03 / 05 / 99$ & 17,1 & 26,6 & 48 & 78 \\
\hline $04 / 05 / 99$ & 16,9 & 27,1 & 51 & 80 \\
\hline $05 / 05 / 99$ & 17,9 & 27,4 & 48 & 79 \\
\hline 06/05/99 & 20,8 & 26,6 & 54 & 73 \\
\hline $07 / 05 / 99$ & 19,4 & 27,1 & 60 & $>90$ \\
\hline 08/05/99 & 19,0 & 24,6 & 53 & 85 \\
\hline $09 / 05 / 99$ & 16,4 & 24,4 & 53 & 76 \\
\hline $10 / 05 / 99$ & 17,3 & 25,4 & 52 & 81 \\
\hline $11 / 05 / 99$ & 17,6 & 24,6 & 54 & 81 \\
\hline $12 / 05 / 99$ & 18,4 & 24,9 & 57 & 88 \\
\hline $13 / 05 / 99$ & 17,1 & 25,1 & 58 & $>90$ \\
\hline $14 / 05 / 99$ & 13,6 & 21,9 & 41 & 78 \\
\hline $15 / 05 / 99$ & 14,0 & 21,6 & 46 & 74 \\
\hline $16 / 05 / 99$ & 13,1 & 21,4 & 53 & 75 \\
\hline $17 / 05 / 99$ & 12,9 & 23,1 & 45 & 77 \\
\hline $18 / 05 / 99$ & 13,8 & 24,1 & 47 & 75 \\
\hline $19 / 05 / 99$ & 14,6 & 25,0 & 48 & 82 \\
\hline
\end{tabular}


Apêndice 7. Temperaturas mínima e máxima e umidade relativa do ar obtidas em leituras diárias durante o período de armazenamento da FCO (continuação)

\begin{tabular}{ccccc}
\hline \multirow{2}{*}{ DATA } & \multicolumn{2}{c}{ TEMPERATURA } & \multicolumn{2}{c}{ UMIDADE RELATIVA } \\
\cline { 2 - 5 } & MíN. $\left({ }^{\circ} \mathrm{C}\right)$ & MÁX. $\left({ }^{\circ} \mathrm{C}\right)$ & MÍN. (\%) & MÁX. (\%) \\
\hline $20 / 05 / 99$ & 13,8 & 26,1 & 40 & 80 \\
$21 / 05 / 99$ & 10,4 & 20,5 & 42 & 72 \\
$22 / 05 / 99$ & 12,3 & 24,4 & 44 & 71 \\
$23 / 05 / 99$ & 11,6 & 20,1 & 43 & 72 \\
$24 / 05 / 99$ & 10,4 & 21,8 & 44 & $>90$ \\
$25 / 05 / 99$ & 13,1 & 22,8 & 49 & 75 \\
$26 / 05 / 99$ & 14,9 & 23,1 & 51 & 78 \\
$27 / 05 / 99$ & 17,6 & 25,9 & 54 & 83 \\
$28 / 05 / 99$ & 18,4 & 25,4 & 59 & 83 \\
$29 / 05 / 99$ & 17,1 & 29,5 & 53 & 84 \\
$30 / 05 / 99$ & 17,1 & 25,5 & 43 & $>90$ \\
$31 / 05 / 99$ & 11,6 & 25,5 & 52 & $>90$ \\
$01 / 06 / 99$ & 9,9 & 20,4 & 50 & 79 \\
$02 / 06 / 99$ & 11,4 & 21,4 & 52 & 78 \\
$03 / 06 / 99$ & 14,0 & 22,1 & 54 & 83 \\
$04 / 06 / 99$ & 14,2 & 21,7 & 58 & 81 \\
$05 / 06 / 99$ & 14,8 & 22,4 & 62 & 83 \\
$06 / 06 / 99$ & 14,9 & 25,3 & 61 & 88 \\
$07 / 06 / 99$ & 12,5 & 20,9 & 63 & 85 \\
$08 / 06 / 99$ & 14,3 & 22,4 & 62 & 88 \\
\hline
\end{tabular}

